\title{
Thermal control of the seismogenic zone of southern central Chile
}

\author{
David Völker, ${ }^{1}$ Ingo Grevemeyer, ${ }^{1}$ Michael Stipp, ${ }^{1}$ Kelin Wang, ${ }^{2}$ and Jiangheng $\mathrm{He}^{2}$ \\ Received 21 January 2011; revised 30 June 2011; accepted 11 July 2011; published 13 October 2011.
}

[1] We developed thermal models for the Chile subduction zone along two profiles at $38.2^{\circ} \mathrm{S}$ and $42^{\circ} \mathrm{S}$ within the rupture area of the $1960 \mathrm{M}=9.5$ Valdivia earthquake and south of the $2010 M=8.8$ Maule earthquake. The age difference of the subducting Nazca Plate has a major impact on the thermal regime, being much younger and hotter in the south. Seafloor heat flow observations confirm this difference but also indicate that in the southern area, heat advection at the outer rise cools the incoming plate. Heat flow values derived from the depth of gas hydrate bottom-simulating reflectors are in general agreement with probe and borehole measurements. The positions where the plate interface reaches temperatures of $100-150^{\circ} \mathrm{C}$ and $350-450^{\circ} \mathrm{C}$ differ between the two profiles. If these temperatures control the updip and downdip limits of the interplate seismogenic zone, the seismogenic zone widens and shifts landward to greater depths from south to north. Observed microseismicity, however, seems to fade at temperatures much lower than $350-450^{\circ} \mathrm{C}$. This discrepancy can be explained in three alternative ways:

(1) deformation in a thick subduction channel controls the seismic/aseismic transition;

(2) microseismicity recorded over a limited time period does not represent the rupture depth of large interface earthquakes; or (3) the serpentinized mantle wedge controls the downdip limit.

Citation: Völker, D., I. Grevemeyer, M. Stipp, K. Wang, and J. He (2011), Thermal control of the seismogenic zone of southern central Chile, J. Geophys. Res., 116, B10305, doi:10.1029/2011JB008247.

\section{Introduction}

[2] Interplate seismicity in subduction zones shows a characteristic spatial distribution. From the tip of the continental margin wedge to 30-60 km landward, often little or no seismicity is observed [Byrne et al., 1988, 1992; Pacheco et al., 1993]. Further landward at the seismic front, interplate seismicity sets in with earthquakes that have focal mechanisms indicating thrust faulting along the subduction interface. Here, large earthquakes that contribute up to $\sim 90 \%$ of the total seismic moment released worldwide are generated [Pacheco and Sykes, 1992]. The seismogenic behavior of the plate interface is limited to depths shallower than 30-60 km [Stern, 2002; Oleskevich et al., 1999].

[3] Updip and downdip limits of the seismogenic zone define the maximum earthquake rupture width which, like the along-strike rupture length, is a major limit for the magnitude of possible earthquakes. The position of the updip limit also affects tsunami hazard. If it is near the trench, large coseismic seafloor uplift is more likely to occur at greater water depths and generate greater tsunami waves.

[4] A common hypothesis is that the position of the interplate seismogenic zone is to the first-order controlled by

\footnotetext{
${ }^{1}$ Collaborative Research Center SFB 574, IFM-GEOMAR Leibniz Institute for Marine Sciences, University of Kiel, Kiel, Germany.

${ }^{2}$ Pacific Geoscience Centre, Geological Survey of Canada, Sidney, British Columbia, Canada.

Copyright 2011 by the American Geophysical Union. 0148-0227/11/2011JB008247
}

temperature [Tichelaar and Ruff, 1993; Ruff and Tichelaar, 1996; Hyndman and Wang, 1993; Hyndman et al., 1995; Oleskevich et al., 1999; Moore and Saffer, 2001], although other factors such as subducting sediments, fluid pressure and the regional stress regime are also likely to play a role [e.g., Wallace et al., 2009]. The updip limit of the seismogenic zone could reflect a temperature-controlled change in the clay mineralogy. Most of this transition occurs between 100 and $150^{\circ} \mathrm{C}$ [Vrolijk, 1990; Hyndman and Wang, 1993; Moore and Saffer, 2001]. Other depth and temperature-dependent processes have been proposed to control the updip limit, such as roughness of the incoming seafloor, cementation and consolidation related to dewatering of subducted sediments, and other metamorphic processes [Marone and Scholz, 1988; Saffer and Marone, 2003]. All these factors and processes change the frictional behavior of the updip fault segment or control shear localization that is important for seismogenic slip [Wang and He, 2008; Wang, 2010].

[5] For the downdip end of the seismogenic zone, a temperature range of $350-450^{\circ} \mathrm{C}$ has been proposed. This temperature range roughly coincides with the onset of plasticity for quartz $\left(\right.$ at $\left.300^{\circ} \mathrm{C}\right)$ and feldspar $\left(\right.$ at $\left.450^{\circ} \mathrm{C}\right)$ [Scholz, 1990]. If the subducting plate comes in contact with the hydrated mantle wedge, interplate seismicity is expected to stop, even before reaching a temperature of $350-450^{\circ} \mathrm{C}$, because the rheology of hydrated mantle material is expected to facilitate stable sliding of the interface [Peacock and Hyndman, 1999]. This latter hypothesis however does not always seem to work. For example, some large thrust earthquakes in northeast 
Japan rupture down to $\sim 60 \mathrm{~km}$, deeper than the Moho depth [e.g., Hino et al., 1996]. This may reflect either complexity in the rheology of hydrated mantle material or heterogeneity in the state of mantle wedge hydration.

[6] The hypothesis that the position of the seismogenic zone depends primarily on temperature or upper plate Moho has been tested at subduction zones of Nankai [Hyndman et al. 1995], Cascadia [Hyndman and Wang, 1993], Costa Rica [Harris and Wang, 2002; Harris et al., 2010], Mexico [Currie et al., 2002] and Alaska as well as Chile [Tichelaar and Ruff, 1991; Oleskevich et al., 1999]. For Nankai, Hyndman et al. [1995] found agreement between the downdip extent of coseismic slip and their modeled $450^{\circ} \mathrm{C}$ limit. Klotz et al. [2006] generally define that (1) the region where the plate contact is at temperatures from $100^{\circ} \mathrm{C}$ to $350^{\circ} \mathrm{C}$ is the interseismic locked zone, (2) the range from 350 to $450^{\circ} \mathrm{C}$ is the zone of transition from full locking to full slip, and (3) the width of the locked zone plus half the width of the transition zone is the seismogenic zone.

[7] Here, we model two profiles of the temperature field across the subduction zone of southern central Chile (Isla Chiloé area at $43^{\circ} \mathrm{S}$ and Isla Mocha area at $38.25^{\circ} \mathrm{S}$ ). The profiles are $530 \mathrm{~km}$ apart and should have major differences in the temperature structure owing to the northward increase in the age of the incoming Nazca Plate. First, we wish to see how the modeled temperature structure relates to the depth distribution of subduction-related small earthquakes that were recorded by local seismic networks during the interseismic period [Bohm et al., 2002; Haberland et al., 2006; Lange et al., 2007]. In particular we want to know how the downdip end of the interplate seismicity compares with the proposed temperature ranges. Second, we wish to compare model-predicted heat flows with those that were either measured with a heat flow probe or in boreholes or calculated from the depth of the methane hydrate bottom-simulating reflectors (BSR) at the continental slope. Misfits between measured and modeled heat flow can provide information about the amount of heat that the upper part of the incoming plate loses owing to the circulation of seawater into the oceanic crust at the outer rise. This process is shown to be active in the area of the southern profile [Contreras-Reyes et al., 2007] and might also affect the northern profile, as the incoming plate has little sediment cover and is severely fractured owing to bending at the outer rise.

[8] We consider southern central Chile, between the Chile Triple Junction at $46^{\circ} \mathrm{S}$ and the Juan Fernandez Ride at $33^{\circ} \mathrm{S}$, an excellent place for these tests because it meets two major conditions:

[9] First, the thermal state of the incoming Nazca Plate varies significantly along strike as a function of plate age. The age of the Nazca Plate at the deformation front increases from $0 \mathrm{Ma}$ at the Chile Triple Junction at $46^{\circ} \mathrm{S}$ to $13 \mathrm{Ma}$ at the Isla Chiloé profile $\left(43^{\circ} \mathrm{S}\right)$, and then to $33 \mathrm{Ma}$ at the Isla Mocha Profile ( $\left.38.25^{\circ} \mathrm{S}\right)$ [Tebbens et al., 1997]. For a very young plate, these age differences have a pronounced influence on the thermal structure of the oceanic lithosphere [e.g., Stein and Stein, 1992].

[10] Second, other parameters that affect seismicity appear to be similar in both areas:

[11] 1. The rate and direction of the subduction of the Nazca Plate beneath the South American Plate is rather uniform, about $6.6 \mathrm{~cm} \mathrm{yr}^{-1}$ at $80.1^{\circ}$ azimuth according to Angermann et al. [1999] or $6.65 \mathrm{~cm} \mathrm{yr}^{-1}$ at $82.4^{\circ}$ according to Kendrick et al. [2003].

[12] 2. The Nazca plate has little hemipelagic sediment cover $(<200 \mathrm{~m})$ seaward of the Chile Trench.

[13] 3. The trench is flooded by turbiditic sediments. Sediment transport within the trench resulted in relatively uniform sediment thickness and seismic facies [Völker et al., 2006]. The thickness at the deformation front is about $2 \mathrm{~km}$.

[14] 4. A fraction of the trench fill is subducted with the Nazca Plate, while the remaining stack is frontally accreted. In southern central Chile, typically $1-1.5 \mathrm{~km}$ (or $50-75 \%$ ) of the trench fill is being subducted [Ranero et al., 2006; Scherwath et al., 2009].

[15] The geometry of the subduction zone, and in particular the dip of the downgoing slab is similar in both profiles, as far as we can infer from the geometry of the WadatiBenioff seismicity [Bohm et al., 2002; Haberland et al., 2006; Lange et al., 2007] and gravity models [Tassara et al., 2006]. In this respect, our model deviates slightly from the thermal model of Oleskevich et al. [1999], which assumes a more curved geometry of the downgoing plate in the southern, Isla Chiloé area. Given these conditions, differences between the two profiles in interplate seismicity are expected to be due predominantly to their different thermal structures.

[16] We need to point out that there are other parameters that we cannot determine at the moment but may influence interplate seismicity:

[17] 1. There may be latitudinal variations in the mechanical properties of the subducted sediment [Röser, 2007; Heberer et al., 2010].

[18] 2. There may be local differences in the amount of subducted sediment offshore of Arauco Peninsula. Seismic reflection line 730 of Bangs and Cande [1997], $40 \mathrm{~km}$ north of our northern profile, shows that the entire sediment stack of $2200 \mathrm{~m}$ is being frontally accreted at present. In contrast, $150 \mathrm{~km}$ further south (line 732 ), only $\sim 25 \%$ of a $1500 \mathrm{~m}$ thick segment is being accreted, and the remaining fraction is subducted. Along our northern profile, subducted sediments can be imaged beneath the coastal cordillera as a $\sim 2 \mathrm{~km}$ wide subduction channel [Sick et al., 2006, Krawcyzk et al., 2006]. TIPTEQ (German abbreviation of project "from the incoming plate to megathrust earthquakes") Corridor 2 which corresponds to our southern profile is characterized by $\sim 1.2 \mathrm{~km}$ thick subducted sediment but $\sim 2 \mathrm{~km}$ of accreted sediment [Scherwath et al., 2009].

[19] 3. The oceanic crust north of the Valdivia Fracture Zone $\left(\sim 40^{\circ} \mathrm{S}\right.$; see Figure 1) was formed at the East Pacific Rise (EPR), but to the south it was formed at the Chile Ridge [Herron et al., 1981; Tebbens et al., 1997]. At the EPR, the Nazca and Pacific plates are diverging at a rate of 134-158 $\mathrm{mm} \mathrm{yr}^{-1}$ [DeMets et al., 1990]. At the Chile Ridge the Nazca and Antarctic plates are diverging at a rate of about $60 \mathrm{~mm} \mathrm{yr}^{-1}$ [DeMets et al., 1990]. This might have given rise to very different histories of seawater percolation near the spreading centers.

[20] The study area is of special significance because it hosted the $M w=9.5$ Valdivia Earthquake of 22 May 1960, the largest earthquake ever instrumentally recorded. The 1960 rupture started at Arauco Peninsula $\left(38,25^{\circ} \mathrm{S}\right)$ and propagated some $1000 \mathrm{~km}$ to the south but little to the north [Plafker and Savage, 1970]. The southward propagation 


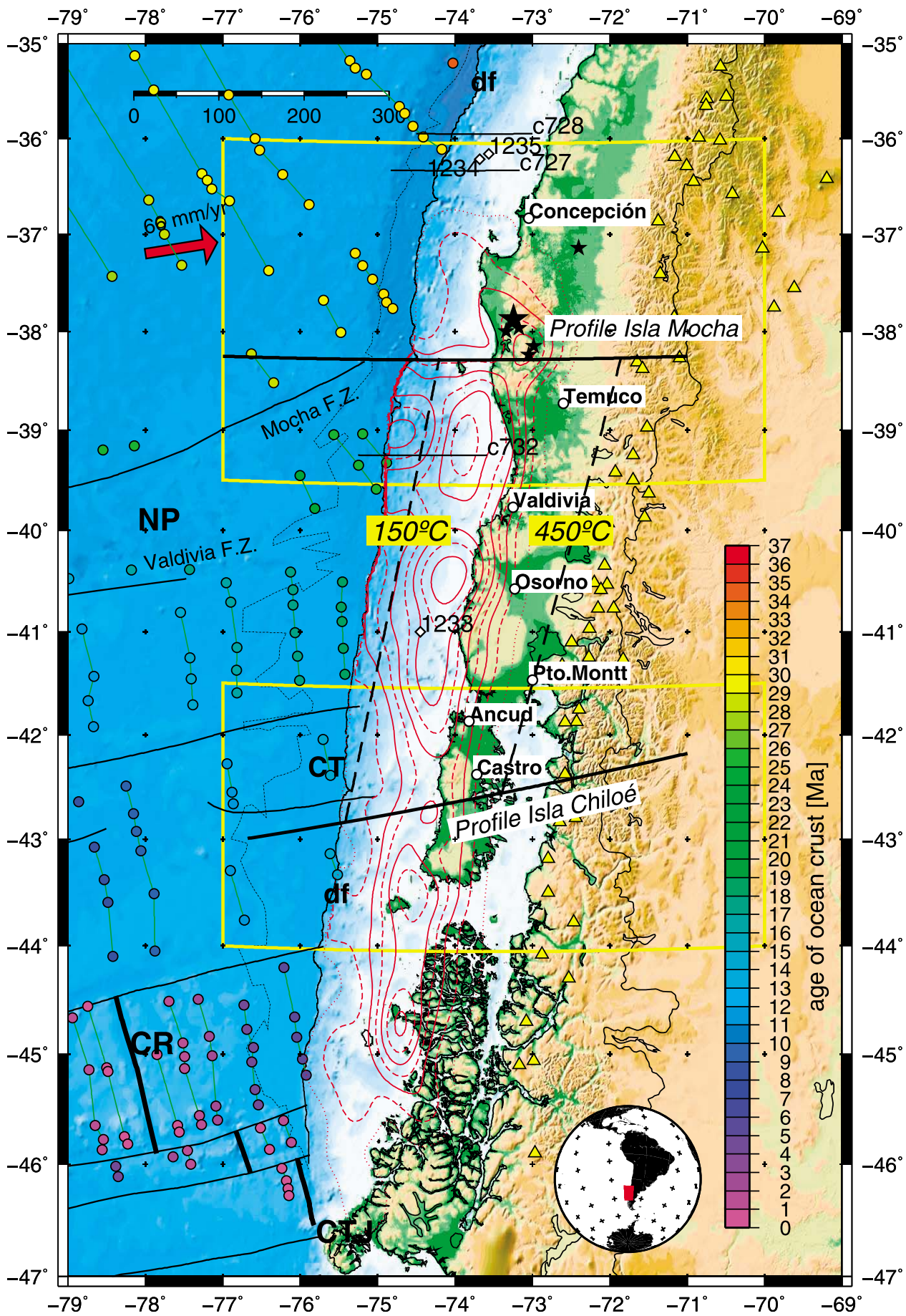

Figure 1. Overview map with the major tectonic features. CR, Chile Ridge; NP, Nazca Plate; CT, sedimentfilled Chile Trench; CTJ, Chile Triple Junction; df, deformation front of the accretionary wedge. The age of the Nazca Plate, according to Tebbens et al. [1997], is symbolized by colored circles. The profiles Isla Mocha and Isla Chiloé and seismic profiles c727, c728, and c732 of R/V Conrad are indicated as solid black lines. The slip distribution of the 1960 earthquake of Moreno et al. [2009] is indicated as red solid, dashed, or dotted lines, and the epicenter of the main shock as large aftershocks of the following days are indicated as smaller black stars [Engdahl and Villaseñor, 2002]. Subduction vector (red arrow) is according to Angermann et al. [1999]. ODP 202 sites [Mix et al., 2003] are given as white diamonds, while active volcanoes are symbolized as yellow triangles. The interpolation of the isotherms of $150^{\circ} \mathrm{C}$ and $450^{\circ} \mathrm{C}$ between both profiles is indicated as a black dotted line. 


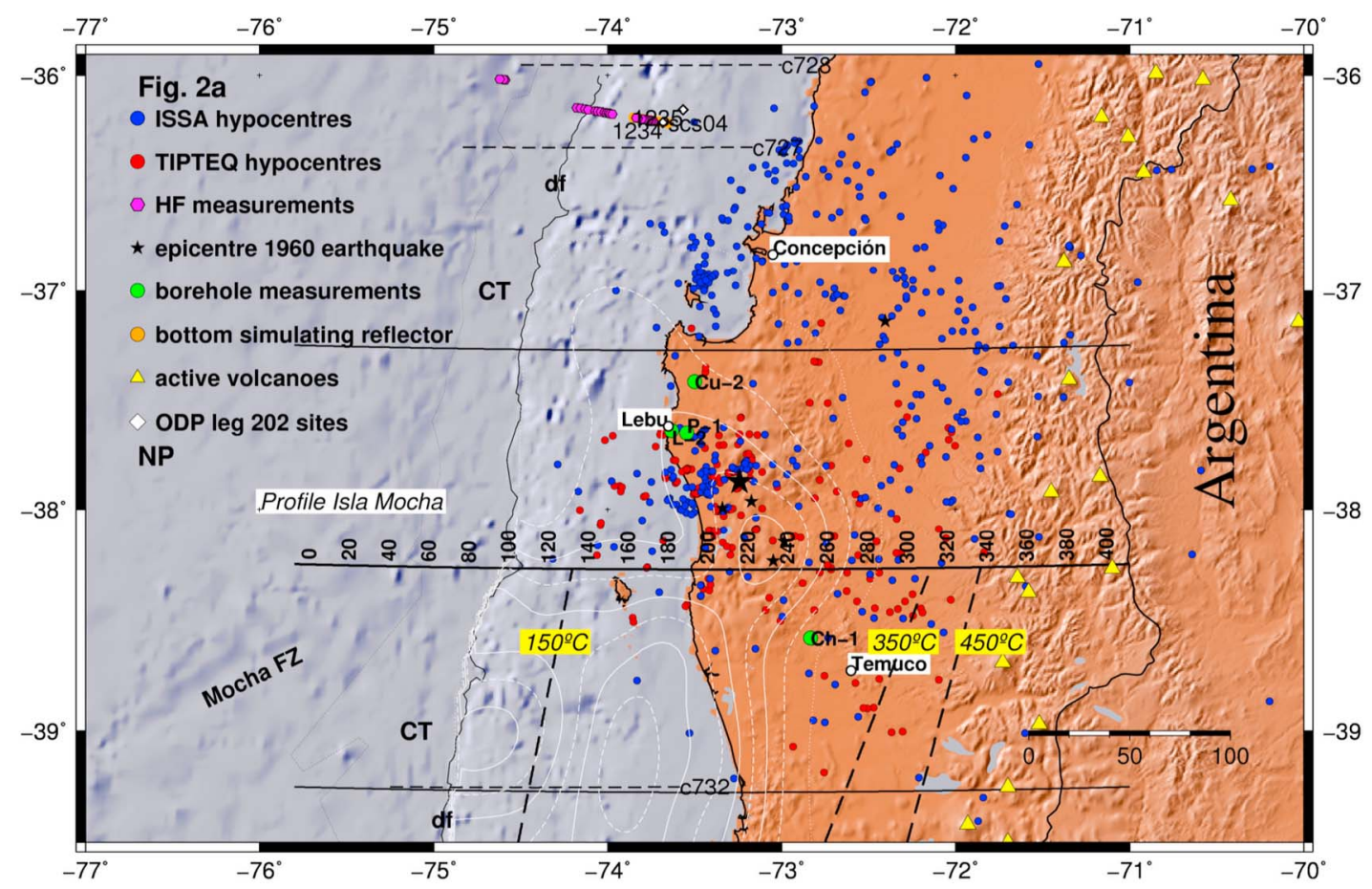

Fig. 2b

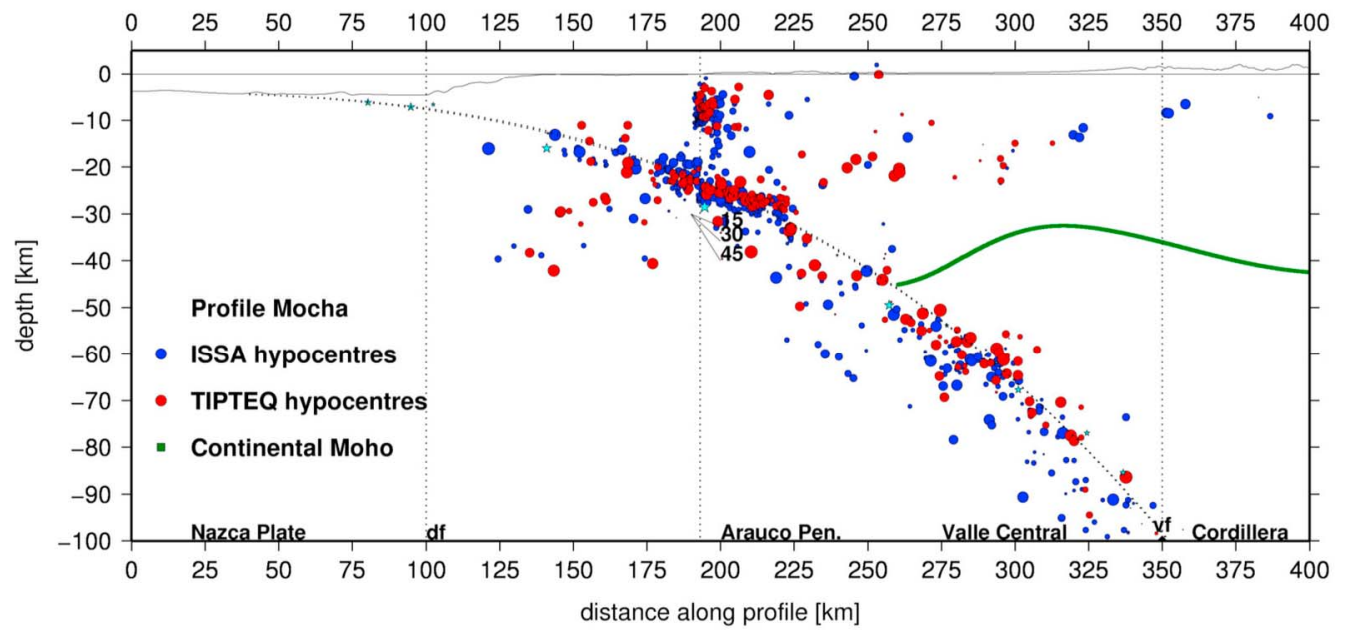

Figure 2. (a) Map of the Isla Mocha region. The Isla Mocha profile and $\mathrm{a} \pm 1^{\circ}$ corridor is indicated with a distance annotation that corresponds to the $x$ axis of Figures $2 \mathrm{~b}, 4 \mathrm{c}, 6$, and 9 . The coseismic slip of the 1960 earthquake [Moreno et al., 2009] is shown as white isolines. Seismic lines c727 and c732 as well as the occurrence of a BSR in the seismic profile TIPTEC-SCS04 [Flueh and Grevemeyer, 2005] are indicated. Boreholes used for thermal rock properties are L-2, Lebu-2; P-1, Pehuen-1; Cu-2, Curanilanue-2; and Ch-1, Cholchol-1 [Munoz and Hamza, 1993]. (b) Profile Isla Mocha with the ISSA TIPTEQ hypocenter data sets that fall into a range $\pm 1^{\circ}$ north and south of the profile. Symbol size corresponds to their distance to our profile. The dotted line is our suggestion for the geometry of the subduction plane. The continental Moho geometry was taken from Alasonati-Tašárová [2007]. Abbreviations are as follows: df, deformation front; NP, Nazca Plate; CT, sediment-filled Chile Trench; vf, volcanic front.

went across several fracture zones and age boundaries of the incoming Nazca plate. In contrast, there seems to have been a barrier to the northward propagation which appears to coincide with the projection of the Mocha Fracture Zone but not with a major change in plate age (see Figures 1 and 2).
[21] We want to test how the positions of the intersections of the plate interface with the $100^{\circ} \mathrm{C}, 350^{\circ}$ and $450^{\circ} \mathrm{C}$ isotherms change from the northern end of the 1960 rupture zone to the south. Barrientos and Ward [1990], and Moreno et al. [2009] used the record of surface deformation of 
Plafker and Savage [1970] to model the coseismic slip of the subduction fault. Their models feature an elongated zone of slip that peaks just beneath the coastline at a depth of $34 \mathrm{~km}$ and terminates at about $50 \mathrm{~km}$ depth (see Figures 1 and 2). For our southern profile, this termination depth lies beneath the east coast of Chiloé Island (Figure 3). For our northern profile, it would be at the eastern flank of the Coastal Cordillera (Figure 2).

[22] The $2010 M w=8.8$ Maule earthquake ruptured a segment north of the 1960 earthquake [Delouis et al., 2010; Farías et al., 2010]. However, coseismic uplift pattern and aftershock seismicity suggest that the event reruptured the epicentral area of the 1960 earthquake. The largest uplift of $2.5 \mathrm{~m}$ was observed on the Arauco Peninsula [Farías et al., 2010]. Therefore, the northern transect provides important information on the thermal structure of the rupture zone of the 2010 Maule earthquake.

\section{Model Description and Observational Constraints}

\subsection{Numerical Model}

[23] Our modeling was performed with the finite element code PGCtherm written by one of the authors $(\mathrm{JH})$. The code was extensively benchmarked [e.g., van Keken et al., 2008] and has been used by Currie et al. [2004], Wada et al. [2008], and Wada and Wang [2009], among others. The model accounts for convective heat transfer within the continental mantle wedge, with viscous mantle wedge flow driven by the downgoing slab. The wedge flow mines heat from greater depths and the back arc and transports it to the arc.

[24] Basic material properties are specific heat $c$, thermal conductivity $k$, and rock density $\rho$. Radiogenic heat production within the continental crust is also included. The nonuniform depth distribution of radiogenic isotopes is accounted for by prescribing an upper crust with higher, and a lower crust with significantly lower, radiogenic heat production.

[25] Frictional heating along the plate interface can serve as a heat source [Molnar and England, 1990]. In the brittle region, the shear stress $\tau$ along the interface is governed by the static friction law $\tau=\mu^{\prime} \sigma_{\mathrm{n}}$, where $\mu^{\prime}$ is the effective coefficient of friction that includes the effects of pore fluid pressure [Wang and He, 2008], and $\sigma_{\mathrm{n}}$ is the normal stress that is approximated with the weight of the overlying rock column. The rate of heat generation per unit fault area is $\mathrm{Q}_{\mathrm{f}}=\tau \mathrm{v}$, where $v$ is the sliding velocity. The forearc mantle is generally considered to be serpentinized and therefore too weak to allow significant friction along the plate interface [Currie et al., 2002].

[26] Globally, there is increasing evidence that low friction is a common property for subduction faults [e.g., Davis and von Huene, 1987; Wang and Hu, 2006; Harris et al., 2010]. For the marine forearc of Chile, on the basis of a comparison of modeled and measured heat flow values, Grevemeyer et al. [2003] consider the contribution of frictional heating negligible. Also from the point of view of critically tapered wedge theory, Hoffmann-Rothe et al. [2006] infer that the basal friction coefficient in southern central Chile has to be much lower than in northern Chile, and they attribute this to the lubrication effect of subducted sediments.
[27] For a sensitivity test of the effect of moderate frictional heating, however, we apply an effective coefficient of friction of 0.03 to 0.05 in accordance with Wang and $\mathrm{Hu}$ [2006], Wang and He [2008], and Harris et al. [2010], which results in a maximum shear stress of 34 to $56 \mathrm{MPa}$ where the subduction fault meets the continental Moho.

\subsection{Observational Constraints and Model Parameters}

\subsubsection{Geometry of the Subduction Zone}

[28] To build the geometry of our models we use geophysical observations that were obtained in the frameworks of the German projects Subduction Processes Offshore Chile, (SPOC) [Krawcyzk, 2003], TIPTEQ ("from the incoming plate to megathrust earthquakes") and the Collaborative Research Centre (SFB 267) "Deformation processes in the Andes" [Oncken et al., 2006].

[29] In the southern Isla Chiloé area, marine wide-angle seismic data show the position of the top of the downgoing plate along our profile from $220 \mathrm{~km}$ offshore to below the coast [Scherwath et al., 2009]. Landward, we use hypocenter locations of an amphibious seismic network that was deployed in 2005 and that have a spatial accuracy in the range of $1.5 \mathrm{~km}$ [Lange et al., 2007].

[30] In the northern Isla Mocha area, a combined marine and land-based wide-angle seismic experiment in line with our profile helps to define the geometry of the slab and Moho [Krawcyzk et al., 2006; Contreras-Reyes et al., 2008]. The Wadati-Benioff Zone is delineated by seismological data of two local networks [Bohm et al., 2002; Haberland et al., 2006]. Haberland et al. [2006] reported a horizontal and vertical accuracy of $1 \mathrm{~km}$ and $0.5 \mathrm{~km}$, respectively, for their hypocenter locations.

[31] Additional constraints for both areas are given by gravity models [Tassara et al., 2006; Alasonati Tašárová, 2007]. The model of Tassara et al. [2006] constrains the top of the subducted slab and the oceanic as well as continental Moho. The model of Alasonati Tašárová [2007] accounts for greater details of the structure of the upper plate between $36^{\circ} \mathrm{S}$ and $42^{\circ} \mathrm{S}$. The model was later extended to $43^{\circ} \mathrm{S}$ by Paolo Alasonati (personal communication, 2008).

\subsubsection{Oceanic Geotherms}

[32] The thermal structure of the incoming plate was calculated using the GDH1 model for the variation of heat flow with lithospheric age [Stein and Stein, 1992]. Equivalently, a temperature profile for very young crust can be calculated using a half-space cooling model with the temperature $T$ as a function of plate age $t$ and depth $z$ as

$$
\mathrm{T}(\mathrm{t}, \mathrm{z})=\mathrm{T}_{\mathrm{m}} \operatorname{erf}(\mathrm{z} / \sqrt{ } 4 \kappa \mathrm{t})
$$

with $T_{m}=1450^{\circ} \mathrm{C}$. Here $\kappa=\mathbf{k} /(\rho \mathbf{c})$ is the thermal diffusivity, with $c=1171 \mathrm{~J} \mathrm{~kg}^{-1}, k=3.138 \mathrm{~W} \mathrm{~m}^{-1} \mathrm{~K}^{-1}$, and $\rho=3330 \mathrm{~kg} \mathrm{~m}^{-3}$.

[33] Hydrothermal circulation of seawater through the oceanic crust can modify the oceanic geotherms. This effect has been proposed to explain low oceanic heat flow values off Costa Rica [Langseth and Silver, 1996; Harris and Wang, 2002]. Hydrothermal circulation could be present in our working area, as the sediment cover of the Nazca Plate is less than $200 \mathrm{~m}$ thick. Also, basement highs stick out locally and might serve as conduits. In the southern area, heat flow measurements point to local hydrothermal 


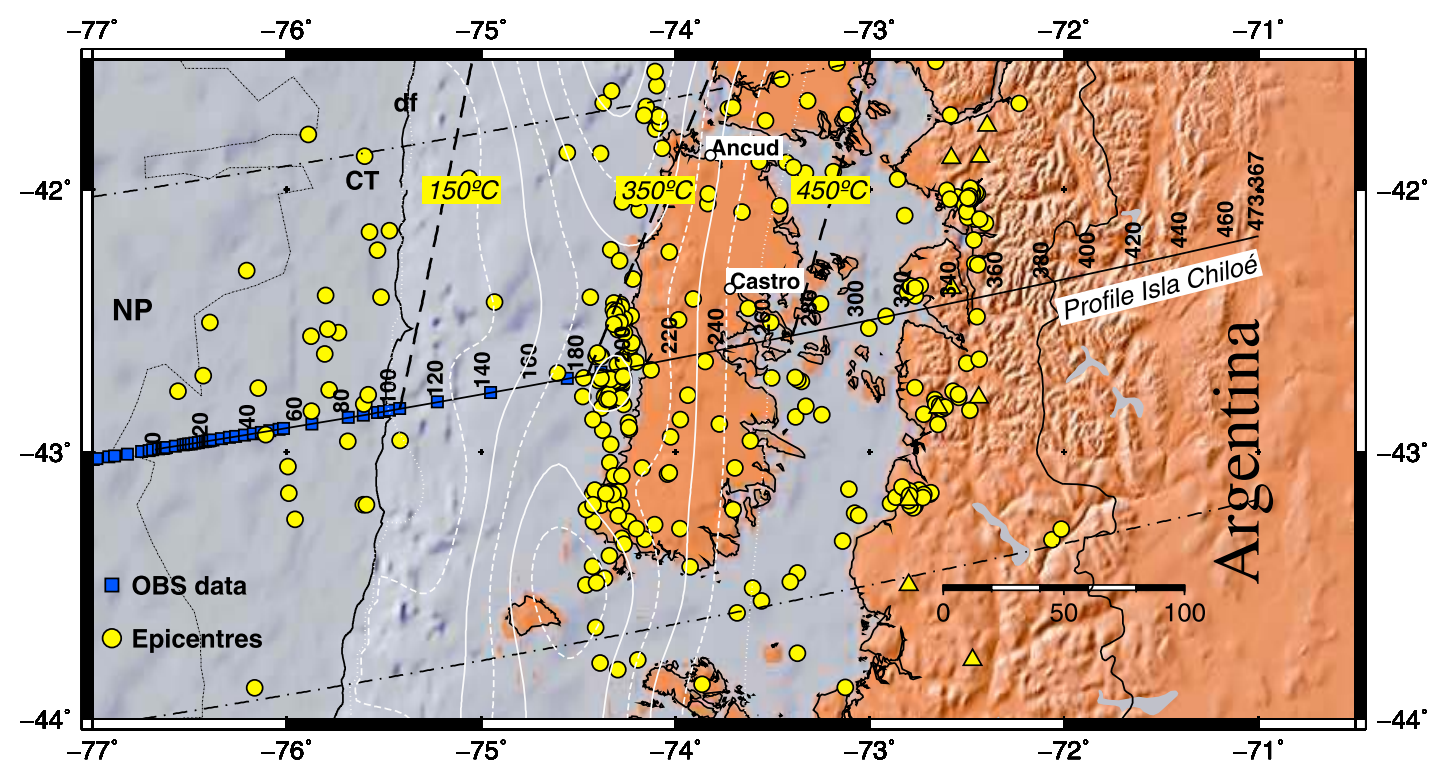

Fig. 3b

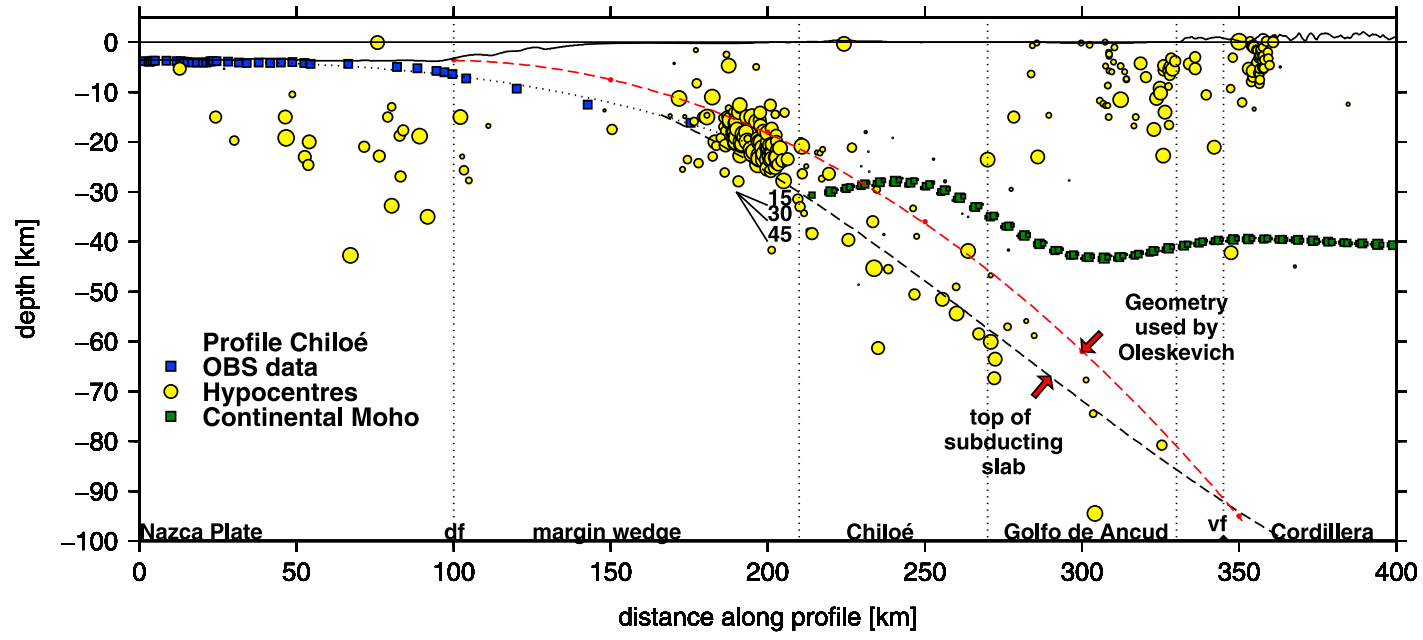

Figure 3. (a) Map of the Chiloé Island region. Our profile Isla Chiloé and a $\pm 1^{\circ}$ corridor is indicated, and the distance annotation corresponds to the $x$ axis of Figures $3 \mathrm{~b}, 4 \mathrm{~b}, 5,7$, and 8 . Blue squares indicate the depth information provided by wide-angle seismic data of Scherwath et al. [2006], and the hypocenter data are from Lange et al. [2007]. The slip distribution of the 1960 earthquake is given as white isolines [Moreno et al., 2009] which, as discussed in section 4.3, may be in large errors. (b) Profile Isla Chiloé. Our preferred model of the upper limit of the downgoing plate is given as a dotted line. For comparison, the geometry used by Oleskevich et al. [1999] is indicated by red dots and a fitted line (upper dotted line). The continental Moho geometry was taken from Alasonati-Tašárová [2007] and Paolo Alasonati (personal communication, 2008). Abbreviations are as follows: df, deformation front; NP, Nazca Plate; CT, sediment-filled Chile Trench; vf, volcanic front.

circulation (see below). We test this effect by applying a "cool" oceanic temperature profile (Figure 4a), with the uppermost section of either 1 or $3 \mathrm{~km}$ thickness set to the bottom water temperature of $2^{\circ} \mathrm{C}$, simulating an isothermal aquifer on top of a cooling half-space. The isothermal section implies very effective cooling that requires vigorous hydrothermal circulation through a fracture network. The hydrothermally perturbed temperature profile is applied to the seaward model boundary, $100 \mathrm{~km}$ seaward of the trench.

\subsubsection{Continental Geotherms and Heat Flow}

[34] Measurements in mines of the Santiago Basin and the adjacent Andes $\left(\sim 33^{\circ} \mathrm{S}\right)$ gave heat flows of $79 \mathrm{~mW} \mathrm{~m}^{-2}$ (La Africana Mine) and $61 \mathrm{~mW} \mathrm{~m}^{-2}$ (La Disputada Mine) [Munoz and Hamza, 1993]. The Coastal Cordillera is characterized by a low heat flow of $27 \pm 11 \mathrm{~mW} \mathrm{~m}^{-2}$ (number of measurements, N: 6), the Central Valley by a value of $70 \pm$ $13 \mathrm{~mW} \mathrm{~m}^{-2}$ (N: 2), the Principal and Patagonian Cordilleras by $160 \pm 63$ and $134 \pm 60 \mathrm{~mW} \mathrm{~m}^{-2}$ (N: 22, resp. 8$)$, and the 

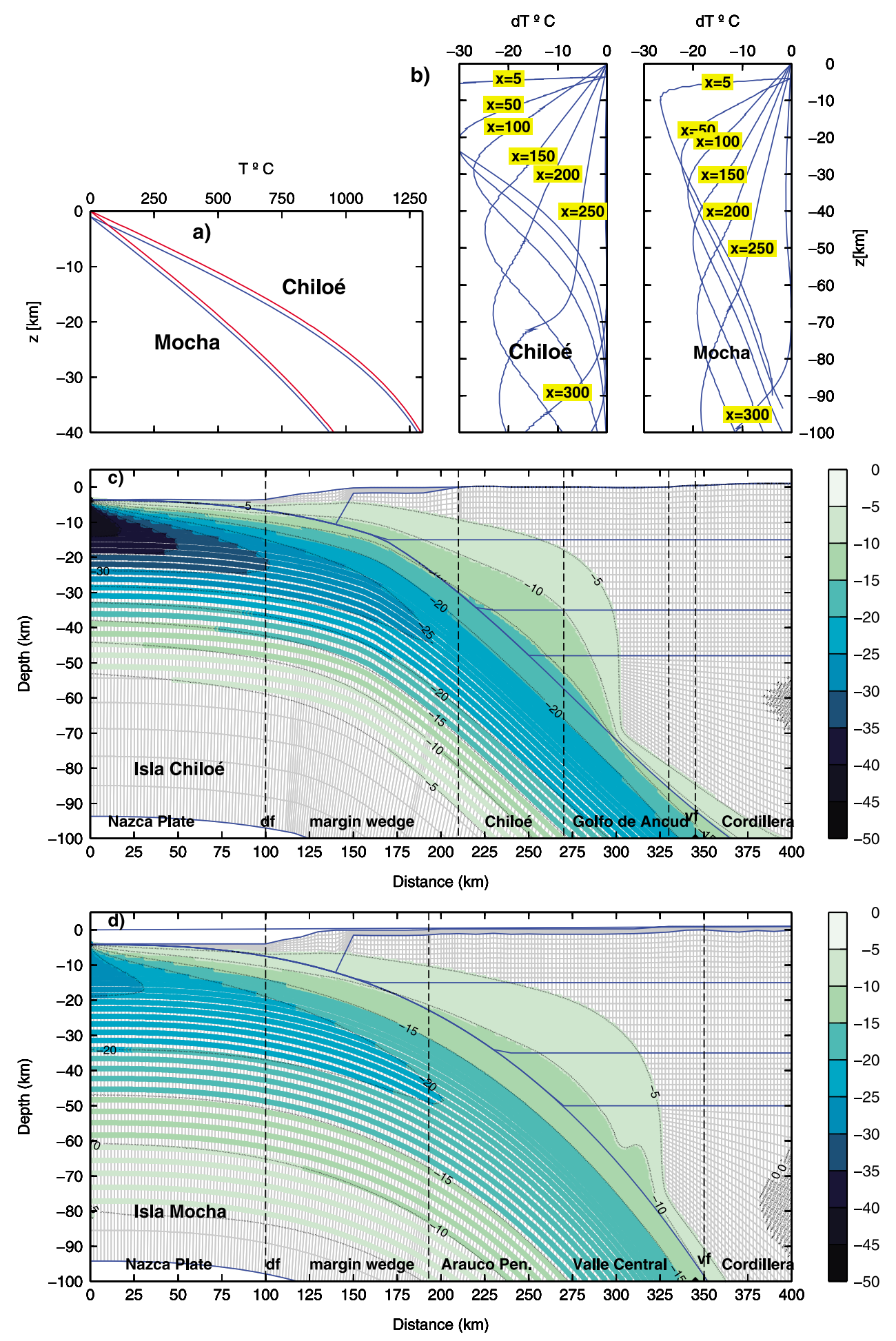

Figure 4. Model results for the thermal field showing the influence of heat loss of the uppermost part of the incoming plate by seawater ventilation. (a) Geotherms for the seaward model boundary according to half-space cooling model [Stein and Stein, 1992] (red line) and for a slab where the upper crust is effectively ventilated to a depth of $1 \mathrm{~km}$ below seafloor (blue line). (b) Evolution of the thermal anomaly with increasing distance $x$ from the model boundary. (c) Thermal anomaly in degrees Celsius for the profile Isla Chiloé due to the introduction of a cool uppermost oceanic crust. (d) Same as Figure $4 \mathrm{c}$ but for the profile Isla Mocha. 
back arc (Neuqén Basin) by $74 \mathrm{~mW} \mathrm{~m}{ }^{-2}$ (N: 1) [Hamza and Munoz, 1996]. Although the data are sparse, they reveal firstorder features such as a Precordilleran belt of low heat flow $\left(<40 \mathrm{~mW} \mathrm{~m}^{-2}\right)$, the main Cordillera of high heat flow $\left(80-100 \mathrm{~mW} \mathrm{~m}^{-2}\right.$ and $\left.>100 \mathrm{~mW} \mathrm{~m}^{-2}\right)$, high variability in local heat flow, and a "normal to hot" back arc with heat flow values in the range of $70-80 \mathrm{~mW} \mathrm{~m}^{-2}$.

[35] The temperature profile assigned to the continental model boundary has to fit the limited heat flow data of the back-arc region (Patagonian Platform) [Hamza and Munoz, 1996]. A value of $74 \mathrm{~mW} \mathrm{~m}{ }^{-2}$, measured in the Neuqén Basin might be representative for the back arc. The value is higher than the average heat flow of $47-49 \mathrm{~mW} \mathrm{~m}^{-2}$ of stable cratonic regions [Rudnick et al., 1998] but comparable to back-arc regions of Cascadia [Davis and Lewis, 1984] and close to the average global continental heat flow of $65 \mathrm{~mW} \mathrm{~m}^{-2}$ [Pollack et al., 1993]. The construction of the continental geotherms follows the model of Rudnick et al. [1998] and Jaupart and Mareschal [1999]. We test several model geothermal gradients, all of which give a surface heat flow of $75 \mathrm{~mW} \mathrm{~m}^{-2}$, on the basis of different assumptions on the distribution of radiogenic heat production. For our standard models, we use a two layer model of the continental crust and margin wedge with a radiogenic heat production of $1.3 \mu \mathrm{W} \mathrm{m} \mathrm{W}^{-3}$ in the upper $10 \mathrm{~km}$ and $0.4 \mu \mathrm{W} \mathrm{m}^{-3}$ in the lower $25 \mathrm{~km}$.

\subsubsection{Oceanic Heat Flow Measurements}

[36] On RV SONNE cruise SO183, seafloor heat flow measurements were made along our southern profile [Flueh and Grevemeyer, 2005]. At a station on the Nazca Plate seaward of our profile, the values vary from 100 to 150 to $\sim 7 \mathrm{~mW} \mathrm{~m}^{-2}$ over $<10 \mathrm{~km}$. This very high scatter and the low minimum values are seen as evidence of crustal cooling by circulation of seawater in the vicinity of a basement outcrop [Contreras-Reyes et al., 2007]. Values scatter around 100$150 \mathrm{~mW} \mathrm{~m}^{-2}$ toward the trench and become more uniform but lower $\left(\sim 70 \mathrm{~mW} \mathrm{~m}^{-2}\right)$ on the outer rise [Flueh and Grevemeyer, 2005]. Additional heat flow measurements are available from the incoming plate to the northwest of the Arauco Peninsula and on the margin wedge. The data show a similar pattern for the northern corridor, indicating that the incoming lithosphere is being cooled by the ventilation of seawater [Grevemeyer et al., 2005].

\subsubsection{BSR-Derived Heat Flow}

[37] The depth of bottom-simulating reflectors (BSRs) that tracks the base of the stability field of methane hydrates in the sediment can be used to calculate heat flux at continental margins [e.g., Grevemeyer and Villinger, 2001; Grevemeyer et al., 2003]. In central Chile Grevemeyer et al. [2003] evaluated BSR occurrences on the continental slope. In particular R/V Conrad seismic profiles c727 and c732 are close to our profile "Isla Mocha" (Figure 2). In these profiles, BSR-derived heat flow values range between 25 and $50 \mathrm{~mW} \mathrm{~m}^{-2} 20-50 \mathrm{~km}$ landward of the deformation front, a pattern disrupted by individual peak-like heat flow anomalies which the authors attribute to localized fluid flow.

[38] We converted BSR data of the seismic profiles TIPTEQ-SCS01, SCS03 and SCS04 of RV SONNE cruise 181-1 into heat flow values. Of these profiles, SCS04 lies $210 \mathrm{~km}$ north of our Isla Mocha profile (Figure 2), whereas SCS01 is identical to our Isla Chiloé profile.
[39] We first picked the two way times (TWT) of the seafloor reflector and of the BSRs and converted them into depth below seafloor $\mathrm{z}$, using the following velocity-depth approximation [Kaul et al., 2000]:

$$
v p(z)=1500+3.451 * z
$$

for $z<100 \mathrm{~m}$ and

$$
v p(z)=1845.1+0.783 *(z-100)
$$

for $100 \mathrm{~m}<z<1000 \mathrm{~m}$

[40] The resultant values for depth and $\mathrm{z}$ were then converted to pressure $p$ and translated to temperature values at the BSR depth $T_{B S R}$ by using the dissociation temperature to pressure relation of Dickens and Quinby-Hunt [1994]:

$$
T(p)=\frac{1}{\left(3.79 * 10^{-3}-2.83 * 10^{-4} * \log (p)\right)}
$$

with $p$ as the hydrostatic pressure in MPa, T in $\mathrm{K}$ and under the assumption of pure methane and seawater salinity of 35 psu.

[41] In order to calculate the heat flow from $T_{B S R}$, we assume a water temperature of $2^{\circ} \mathrm{C}$ and need values for thermal conductivity $k$, averaged from the seafloor to the depth of the BSR $z$. The thermal conductivity of watersaturated sediments is a bulk value that can be calculated from matrix and fluid conductivities $\left(3.9\right.$ and $\left.0.6 \mathrm{~W} \mathrm{~m}^{-1} \mathrm{~K}^{-1}\right)$ and porosity $\varphi$ [Brigaud and Vasseur, 1989]. In our case, we use a mean value of $0.85 \mathrm{~W} \mathrm{~m}^{-1} \mathrm{~K}^{-1}$ derived from ODP leg 202 sites 1235 and 1234 close to the profile [Grevemeyer et al., 2003, Figure 2, Table 2], which produced a close fit of measured and BSR-derived heat flow values. The final surface heat flow values are obtained with the basic equation

$$
Q=-k \frac{d T}{d z}
$$

\subsubsection{Thermal Properties of Crust and Lithospheric Mantle}

[42] Direct measurements of the thermal properties of the forearc rocks were made in boreholes of the Arauco Peninsula [Munoz and Hamza, 1993]. The boreholes Pehuen-1, Lebu-2, Curanilahue-2 and Cholchol-1 penetrate $1500 \mathrm{~m}$, the mean values are given in Table 1 . We use standard literature values for the thermal properties of the oceanic and continental crust. A list of selected values for rock heat capacity is given in Table 1, and a list of selected conductivity values in Table 2.

\subsubsection{Rheological Properties of the Mantle Wedge}

[43] The rheology of the mantle is described as either isoviscous or stress and temperature dependent. A power law rheology based on laboratory experiments is generally used to describe the thermally activated creep of rocks [e.g., Brace and Kohlstedt, 1980; Ranalli and Murphy, 1987; Kohlstedt et al., 1995]. We tested both the isoviscous rheology (with a viscosity of $4.0 \times 10^{19} \mathrm{~Pa}$ ) and the power law rheology for dislocation creep of wet olivine [Chopra and Paterson, 1984; Karato et al., 1986; Mei and Kohlstedt, 2000; Hirth and Kohlstedt, 2003]. 
Table 1. Selected Heat Capacity Values From Various Sources

\begin{tabular}{|c|c|c|c|c|}
\hline$\left(\mathrm{MJ} \mathrm{m}^{-3} \mathrm{~K}^{-1}\right)$ & $\left(\begin{array}{c}\mathrm{c} \\
\left(\mathrm{Jg}^{-1} \mathrm{~K}^{-1}\right)\end{array}\right.$ & Rock Type & Region & Reference \\
\hline 3.3 & 1171 & oceanic crust & - & $\begin{array}{l}\text { Oleskevich et al. } \\
\text { [1999] }\end{array}$ \\
\hline 3.3 & & oceanic crust & Nicoya & $\begin{array}{l}\text { Harris and Wang } \\
\text { [2002] }\end{array}$ \\
\hline 2.68 & 958 & granite (mean) & - & Rummel [1982] \\
\hline \multirow{5}{*}{2.74} & 899 & basalt (mean) & - & Rummel [1982] \\
\hline & 1013 & quartzite (mean) & - & Rummel [1982] \\
\hline & 1134 & $\begin{array}{l}\text { amphibolite } \\
\text { (mean) }\end{array}$ & - & Rummel [1982] \\
\hline & 820 & andesite & - & Rummel [1982] \\
\hline & 1010 & peridotite & - & Rummel [1982] \\
\hline \multirow[t]{4}{*}{2.6} & & marine sediments & Nicoya & $\begin{array}{l}\text { Harris and Wang } \\
\text { [2002] }\end{array}$ \\
\hline & 933 & limestone & - & Rummel [1982] \\
\hline & 1640 & sandstone & - & Rummel [1982] \\
\hline & 970 & sandstone & - & Rummel [1982] \\
\hline
\end{tabular}

[44] Heat flow measurements and several lines of evidence indicate that the wedge flow extend very little into the forearc [Wada et al., 2008]. Wada et al. [2008] showed that the stagnation of the (hydrated) forearc mantle wedge is because of mechanical decoupling from the slab. Wada and Wang [2009] further proposed that a depth of mantle-slab decoupling at $70-80 \mathrm{~km}$ is common to most subduction zones. Wada et al. [2008] also showed the termination of the decoupling to be very abrupt, such that the transition from the stagnant to flowing parts of the mantle wedge is extremely sharp. We therefore follow Peacock and Wang [1999] and Currie et al. [2004] to use the simplified approach of imposing a nonflow wedge nose, instead of directly modeling the stagnation of the wedge nose using stress decoupling. The vertical boundary of the no-flow zone is located where the plate interface is $70 \mathrm{~km}$ deep.

\subsection{Model Description}

\subsubsection{Profile Isla Chiloé}

[45] A transect with wide-angle seismic profiles and seafloor heat flow measurements was established during the RV SONNE cruise SO181 (TIPTEQ-corridor 4) [Flueh and Grevemeyer, 2005]. Our profile is in line with this transect but extends on land for another $200 \mathrm{~km}$. It starts $100 \mathrm{~km}$ west of the deformation front $\left(78.5^{\circ} \mathrm{W} / 43.2^{\circ} \mathrm{S}\right)$ and extends across the island of Chiloé, the Gulf of Ancud and the

Table 2. Selected Values for Thermal Conductivities of Rocks Used in Thermal Models of Subduction Zones

\begin{tabular}{|c|c|c|c|}
\hline $\mathrm{k}\left(\mathrm{W} \mathrm{m}{ }^{-1}{ }^{\circ} \mathrm{C}^{-1}\right)$ & Rock Type & Region & Reference \\
\hline \multicolumn{4}{|c|}{ Oceanic Crust } \\
\hline 2.9 & oceanic crust & Chile & Oleskevich et al. [1999] \\
\hline 2.9 & oceanic crust & SW Japan & Oleskevich et al. [1999] \\
\hline 2.9 & oceanic crust & Alaska & Oleskevich et al. [1999] \\
\hline 2.9 & oceanic crust & Cascadia & Oleskevich et al. [1999] \\
\hline 2.9 & oceanic crust & Nicoya & Harris and Wang [2002] \\
\hline 2,9 & oceanic lithosphere & U.S. West Coast & English et al. [2003] \\
\hline \multicolumn{4}{|c|}{ Continental Crust } \\
\hline 3.0 & continental crust & Chile & Oleskevich et al. [1999] \\
\hline 2.5 & continental crust & SW Japan & Oleskevich et al. [1999] \\
\hline $2.5-3.0$ & continental crust & Alaska & Oleskevich et al. [1999] \\
\hline $2.5-3.0$ & continental crust & Cascadia & Oleskevich et al. [1999] \\
\hline 2.7 & continental crust $(0-20 \mathrm{~km})$ & Nicoya & Harris and Wang [2002] \\
\hline 2.7 & continental crust $(20-40 \mathrm{~km})$ & Nicoya & Harris and Wang [2002] \\
\hline 2.5 & continental crust & Cascadia & Currie et al. [2004] \\
\hline 2.5 & continental lithosphere & U.S. West Coast & English et al. [2003] \\
\hline \multicolumn{4}{|c|}{ Accretionary Prism } \\
\hline $1.75-2.5$ & accretionary prism & Chile & Oleskevich et al. [1999] \\
\hline $2.0-2.5$ & accretionary prism & SW Japan & Oleskevich et al. [1999] \\
\hline $1.5-2.5$ & accretionary prism & Alaska & Oleskevich et al. [1999] \\
\hline $1.5-2.5$ & accretionary prism & Cascadia & Oleskevich et al. [1999] \\
\hline \multicolumn{4}{|c|}{ Mantle Wedge } \\
\hline 2.9 & mantle wedge & Nicoya & Harris and Wang [2002] \\
\hline 3.1 & mantle & Cascadia & Currie et al. [2004] \\
\hline \multicolumn{4}{|c|}{ Sediments } \\
\hline $0.6-1.1$ & biogenic oozes & ODP sites $1233-1235$ & Grevemeyer et al. [2003] \\
\hline 0.85 & average of sites & ODP sites $1233-1235$ & Grevemeyer et al. [2003] \\
\hline $0.93-0.97$ & calcareous oozes & NE Atlantic & Jones [1999] \\
\hline 1.00 & calcareous oozes & Pacific & Jones [1999] \\
\hline 0.97 & clayey calcareous ooze & Pacific & Jones [1999] \\
\hline 0.87 & calc./silic. ooze & Pacific & Jones [1999] \\
\hline $0.72-0.99$ & abyssal clay & Pacific & Jones [1999] \\
\hline $0.87-1.0$ & black mud & Mediterranean & Jones [1999] \\
\hline 1.2 & sediments & Nicoya & Harris and Wang [2002] \\
\hline \multicolumn{4}{|c|}{ Sedimentary and Metamorphic Units of Arauco Peninsula } \\
\hline $2.38 \pm 0.74$ & borehole & Lebu-2 (Figure 2) & Munoz and Hamza [1993] \\
\hline $2.3 \pm 0.7$ & borehole & Pehuen-1 (Figure 2) & Munoz and Hamza [1993] \\
\hline $3.02 \pm 0.75$ & borehole & Curanilahue-2 (Figure 2) & Munoz and Hamza [1993] \\
\hline
\end{tabular}


Andean Cordillera into the Patagonian Basin (Figure 3). At $x=0,100 \mathrm{~km}$ seaward of the trench, the age of the incoming plate is $13 \mathrm{Ma}$.

[46] The distribution of microseismicity of Lange et al. [2007] including 364 events that were recorded over a period of 11 months shows a largely aseismic zone from the wedge tip to the upper continental slope $(x=170 \mathrm{~km})$, a cluster of thrust-type events below and west of the western shore of Chiloé Island, a train of events which depict the downgoing slab between 30 and $70 \mathrm{~km}$ depth, and a shallow cluster related to the Liquini-Ofqui Fault Zone and local volcanoes (Figure 3b).

[47] The slab geometry was constructed with polynomial fits through data points from wide-angle seismic data [Scherwath et al., 2009] and the projection of hypocenter data of Lange et al. [2007] within a distance of $\pm 100 \mathrm{~km}$ onto the profile with the GMT tools [Wessel and Smith, 1998]. The plate interface dips with $4^{\circ}$ at the trench, reaches a depth of $33 \mathrm{~km}$ below the western coast of Chiloé, dips $23-25^{\circ}$ below Chiloé and has a depth of $95 \mathrm{~km}$ below the active volcanic front (Figure $3 b$ ). The dip and curvature is similar to the northern profile. Compared to the geometry Oleskevich et al. [1999] used, it lies deeper and is less curved in the onshore part of the profile. Both models assume a similar slab depth beneath the arc (Figure $3 b$ ).

[48] The mantle is divided into an upper solid part and a viscous portion below $50 \mathrm{~km}$, where mantle flow is permitted. In most models, the continental Moho is taken as a horizontal boundary at $35 \mathrm{~km}$ depth. For testing purpose, the Moho geometry based on gravity modeling of AlasonatiTašárová [2007] was adapted to one model. The main difference is an upward bulge of the continental mantle beneath the island of Chiloé and a less pronounced downward bulge beneath the Gulf of Ancud (see Figure 3b).

[49] The continental crust is subdivided into three parts. The most seaward part represents the sedimentary accretionary wedge that abuts a backstop of upper continental crust (e.g., Figures $4 b$ and $4 c$ ). Although this transition is gradual as the continental backstop is made of a Tertiary accretionary wedge [Bangs and Cande, 1997], it can be traced as a rather steep $p$ wave velocity gradient in seismic tomography models [Contreras-Reyes et al., 2008; Scherwath et al., 2009]. In order to account for a depth distribution of heat producing elements (HPE) a horizontal boundary at $\mathrm{z}=15 \mathrm{~km}$ divides upper and lower continental crust.

\subsubsection{Profile "Isla Mocha"}

[50] Our northern profile runs $\mathrm{W}-\mathrm{E}$ at $38.25^{\circ} \mathrm{S}$. It is in line with the combined land and sea based seismic experiment line SPOC south [Krawcyzk et al., 2006] and crosses the epicenter of the 1960 earthquake. The profile starts $100 \mathrm{~km}$ seaward of the deformation front $\left(75.7^{\circ} \mathrm{W} / 38.25^{\circ} \mathrm{S}\right)$. It crosses the trench just north of Mocha Island, and runs across the Coastal Cordillera, Central Valley and Main Cordillera into the Neuqén back-arc basin (Figure 2b). At $x=0,100 \mathrm{~km}$ seaward of the deformation front, the age of the incoming plate is $\sim 33 \mathrm{Ma}$.

[51] The project ISSA installed a temporary network of 62 stations that registered 333 events over a period of 3 months between $36^{\circ} \mathrm{S}$ and $40^{\circ} \mathrm{S}$ [Bohm et al., 2002]. Under the TIPTEQ project, a 1 year local network was set up in the Arauco area [Haberland et al., 2006]. One main feature of the hypocenter distribution is an east-dipping band, with a dip of about $10^{\circ}$ between $73^{\circ} \mathrm{W}$ and $74^{\circ} \mathrm{W}$ and about $30^{\circ}$ further to the east (Figure $2 \mathrm{~b}$ ). The events forming this band have a first maximum density beneath the coast (at around $18-30 \mathrm{~km}$ depth), a kind of intermediate gap and a second maximum below $55 \mathrm{~km}$ depth. The cluster beneath the coast was attributed to events at the plate interface by Haberland et al. [2006]. The second maximum consists of events within the slab and was associated with dehydration processes by Bohm et al. [2002]. Both data sets fit well together and allow the construction of the model's geometry (Figure 2b).

[52] We built the geometry in the same way as described for the Isla Chiloé Profile. The resulting geometry shows a slab with a dip of $5^{\circ}$ at the trench, increasing to $15^{\circ}$ beneath the coast and $30^{\circ}$ beneath the Central Valley and Main Cordillera (Figure 2b). Again, the slab is at a depth of $\sim 100 \mathrm{~km}$ beneath the volcanic front. We kept the geometry of the continental Moho simple (horizontal boundary). To fit gravity data, there is some need for an upward mantle wedge bulge to account for excess gravity [Alasonati Tašárová, 2007] (see also Figure 2b). This bulge is less pronounced than further south.

\section{Results}

[53] Uncertainties are to be expected in the geometry of the models, but we have little degree of freedom in modifying it, as it is quite well constrained by a number of data sets as described in section 2.3. Uncertainties resulting from changing the crustal thermal properties within reasonable ranges are small [see also Harris et al., 2010]. The geothermal gradient of the landward model boundary has direct influence on the temperature field of the back arc, but we are mainly interested in the forearc temperature. Different models of the mantle wedge rheology do not significantly affect the forearc because of the effect of decoupling discussed above (section 2.1). As is well known [e.g., Peacock and Wang, 1999], the thermal structure of the incoming plate has the first-order control on the subduction zone thermal field.

\subsection{Influence of Hydrothermal Cooling of the Oceanic Crust}

[54] The temperature difference between the model with a hydrothermally cooled incoming plate (as explained in section 2.2.2) and the model with a GDH1-defined incoming plate shows the effects of such cooling and how the effects decrease away from the seaward boundary (Figure 4b). The difference is the most prominent along the seaward boundary at the maximum depth of assumed crustal ventilation. Here, instead of a temperature of $47^{\circ} \mathrm{C}$ for Chiloé and $27^{\circ} \mathrm{C}$ for Mocha as predicted by the GDH1 model, a temperature of $2^{\circ} \mathrm{C}$ is assumed, the same as the seafloor. As the cooling anomalies are transported into the subduction zone with the slab, they gradually diminish by conduction. Because the subduction rate is high, the perturbations persist over most of the model profiles (Figures $4 b-4 d$ ). For the young and hot oceanic crust of the southern profile, because the initial perturbation is much greater, its impact on the temperature field is much more pronounced (Figures $4 \mathrm{c}$ and $4 \mathrm{~d}$ ). This process decreases the plate interface temperature by about $10-20^{\circ} \mathrm{C}$ landward of the trench (Figures $4 \mathrm{c}$ and $4 \mathrm{~d}$ ), corresponding to a landward shift of the $150^{\circ} \mathrm{C}, 350^{\circ}$ and $450^{\circ} \mathrm{C}$ 
Table 3. Model Results for the Length and Position of the Seismogenic Zone for the Chiloé and Isla Mocha Profiles ${ }^{\mathrm{a}}$

\begin{tabular}{|c|c|c|c|c|c|c|c|c|}
\hline & \multicolumn{8}{|c|}{ Position at Décollement $(\mathrm{km})$} \\
\hline & \multicolumn{2}{|c|}{ Isoviscous Mantle } & \multicolumn{2}{|c|}{$\underline{\text { Power Law Mantle }}$} & \multicolumn{2}{|c|}{ Cool Crust $(1 \mathrm{~km})$} & \multicolumn{2}{|c|}{$\underline{\text { Cool Crust }(3 \mathrm{~km})}$} \\
\hline & $\mathrm{x}$ & $\mathrm{z}$ & $\mathrm{x}$ & $\mathrm{z}$ & $\mathrm{x}$ & $\mathrm{z}$ & $\mathrm{x}$ & $\mathrm{z}$ \\
\hline \multicolumn{9}{|c|}{ Chiloé Model } \\
\hline $100^{\circ} \mathrm{C}$ & 79 & 6 & 79 & 6 & 83 & 6 & 93 & 6 \\
\hline $150^{\circ} \mathrm{C}$ & 104 & 7 & 104 & 7 & 108 & 7 & 117 & 8 \\
\hline $350^{\circ} \mathrm{C}$ & 184 & 24 & 184 & 24 & 199 & 29 & 231 & 42 \\
\hline Wedge tip & 208 & 31 & 208 & 31 & 208 & 31 & 208 & 31 \\
\hline $450^{\circ} \mathrm{C}$ & 272 & 61 & 271 & 60 & 283 & 66 & 297 & 72 \\
\hline Length locked zone ${ }^{\mathrm{b}}(\mathrm{km})$ & & 105 & & 105 & & 116 & & 138 \\
\hline Length transition zone ${ }^{\mathrm{c}}(\mathrm{km})$ & & 88 & & 87 & & 84 & & 66 \\
\hline Length seismogenic zone ${ }^{\mathrm{d}}(\mathrm{km})$ & & 149 & & 149 & & 158 & & 171 \\
\hline Length seismogenic zone $e^{\mathrm{e}}(\mathrm{km})$ & & 129 & & 129 & & 125 & & 115 \\
\hline \multicolumn{9}{|c|}{ Mocha Model } \\
\hline $100^{\circ} \mathrm{C}$ & 102 & 8 & & & 105 & 8 & 114 & 9 \\
\hline $150^{\circ} \mathrm{C}$ & 131 & 11 & & & 137 & 15 & 152 & 14 \\
\hline $350^{\circ} \mathrm{C}$ & 311 & 72 & & & 319 & 77 & 324 & 81 \\
\hline Wedge tip & 259 & 45 & & & 259 & 45 & 259 & 45 \\
\hline $450^{\circ} \mathrm{C}$ & 336 & 88 & & & 338 & 90 & 344 & 94 \\
\hline Length locked zone ${ }^{\mathrm{b}}(\mathrm{km})$ & & 209 & & & & 214 & & 210 \\
\hline Length transition zone ${ }^{\mathrm{c}}(\mathrm{km})$ & & 25 & & & & 19 & & 20 \\
\hline Length seismogenic zone $^{\mathrm{d}}(\mathrm{km})$ & & 222 & & & & 224 & & 220 \\
\hline Length seismogenic zone ${ }^{\mathrm{e}}(\mathrm{km})$ & & 157 & & & & 154 & & 145 \\
\hline
\end{tabular}

${ }^{\mathrm{a}}$ Definitions of locked zone, transition zone, and seismogenic zone are after Klotz et al. [2006].

${ }^{\mathrm{b}}$ Where $x\left(350^{\circ} \mathrm{C}\right)-x\left(100^{\circ} \mathrm{C}\right)$.

${ }^{\mathrm{c}}$ Where $x\left(450^{\circ} \mathrm{C}\right)-x\left(350^{\circ} \mathrm{C}\right)$.

${ }^{\mathrm{d}}$ Where $x\left(350^{\circ} \mathrm{C}\right)-x\left(100^{\circ} \mathrm{C}\right)+0.5^{*}\left(x\left(450^{\circ} \mathrm{C}\right)-x\left(350^{\circ} \mathrm{C}\right)\right)$

${ }^{\mathrm{e}}$ Where $x$ (wedge tip) $-x\left(100^{\circ} \mathrm{C}\right)$.

isotherms by 3 to $30 \mathrm{~km}$ (see Table 3 and Figures $5 \mathrm{~b}$ and $6 \mathrm{~b}$ ). The change in the widths of the zones defined by these isotherms is up to $22 \mathrm{~km}$ (Table 3 ). The effect on surface heat flow is most pronounced near the seaward boundary, where values are lowered by up to $80 \mathrm{~mW} \mathrm{~m}^{-2}$ in the case of $3 \mathrm{~km}$ cooling depth (see blue lines in Figures 5a and 6a). The anomaly is in the range of a few $\mathrm{mW} \mathrm{m}^{-2}$ on land.

\subsection{Influence of Mantle Wedge Rheology}

[55] The introduction of a nonlinear stress- and temperature-dependent rheology of the mantle results in mantle flow patterns that are quite different from those of an isoviscous mantle. As a consequence, a more pronounced heat transport within the mantle wedge has been modeled.

[56] When we apply a nonlinear rheology to our Chiloé model, a flow pattern with fast upflow and downflow within a narrower band parallel to the subducting plate is observed (Figures $7 \mathrm{a}$ and $7 \mathrm{~b}$ ). The enhanced flow results in higher mantle temperatures beneath the arc and a steeper temperature gradient at the boundary of the no-flow zone (see section 2.2.7) where the flow ends (Figures 7c and 7d). As a consequence, interface temperatures are increased by up to $100^{\circ} \mathrm{C}$ above the flowing part of the mantle (see green line in Figure 5b). This however has no effect on the downdip end of the thermally defined seismogenic zone. The surface heat flow on Chiloé Island is increased by $20-25 \mathrm{~mW} \mathrm{~m}^{-2}$ in comparison with the isoviscous case. The effect would be much stronger and would propagate further into the forearc if the flow into the wedge tip were not restricted by the decoupling effect discussed in section 2.2.7.

\subsection{Influence of Continental Moho Geometry}

[57] We observe very little difference between the results of the "simple" and "complex" Moho geometry models for the Chiloé profile (result not shown). This is expected, as the Moho variations do not affect the mantle flow (which is to be deeper than $50 \mathrm{~km}$ ) but only the distribution of heat producing elements.

\subsection{Influence of Thermal Properties of the Crust}

[58] For the accretionary wedge, the tested range of thermal conductivity was $0.8-2.0 \mathrm{~W} \mathrm{~m} \mathrm{~m}^{-1} \mathrm{~K}^{-1}$ and the heat capacity range was $2.0-2.8 \mathrm{MJ} \mathrm{m}^{-3} \mathrm{~K}^{-1}$ according to the studies listed in Tables 1 and 2. For the continental crust, we tested values ranging from 2.5 to $3.0 \mathrm{~W} \mathrm{~m}^{-1} \mathrm{~K}^{-1}$ and 2.6-2.8 $\mathrm{MJ} \mathrm{m}^{-3} \mathrm{~K}^{-1}$. The most prominent variations in the temperature field are produced by changes in conductivity of the continental crust and accretionary wedge, but the effect is restricted to those parts of the model. The surface heat flow is raised or lowered by about $15 \mathrm{~mW} \mathrm{~m}^{-2}$ by changes in the thermal conductivity in the given range.

\subsection{Influence of Frictional Heating}

[59] Moderate frictional heating with an effective coefficient of friction of 0.03 to 0.05 , leading to a maximum shear stress of $34 \mathrm{MPa}$ to $56 \mathrm{MPa}$ at the plate interface, raises the surface heat flow by up to $20 \mathrm{~mW} \mathrm{~m}^{-2}$ seaward of the trench and by around $2-5 \mathrm{~mW} \mathrm{~m}^{-2}$ on the continental slope (Figure 5a). This increase in the modeled surface heat flow does no match observed values which are even below the no-friction model curve. The effect on the subduction fault temperature is in the range of about $10^{\circ} \mathrm{C}$ and this increase shifts the positions of the $150^{\circ} \mathrm{C}, 350^{\circ} \mathrm{C}$ and $450^{\circ} \mathrm{C}$ isotherms on the subduction fault by 10 to $15 \mathrm{~km}$ seaward (Figure $5 \mathrm{~b}$ ).

\subsection{Profile Isla Chiloé}

[60] Our models show a simple isotherm geometry (Figure 8). The subduction of the slab leads to a downward 


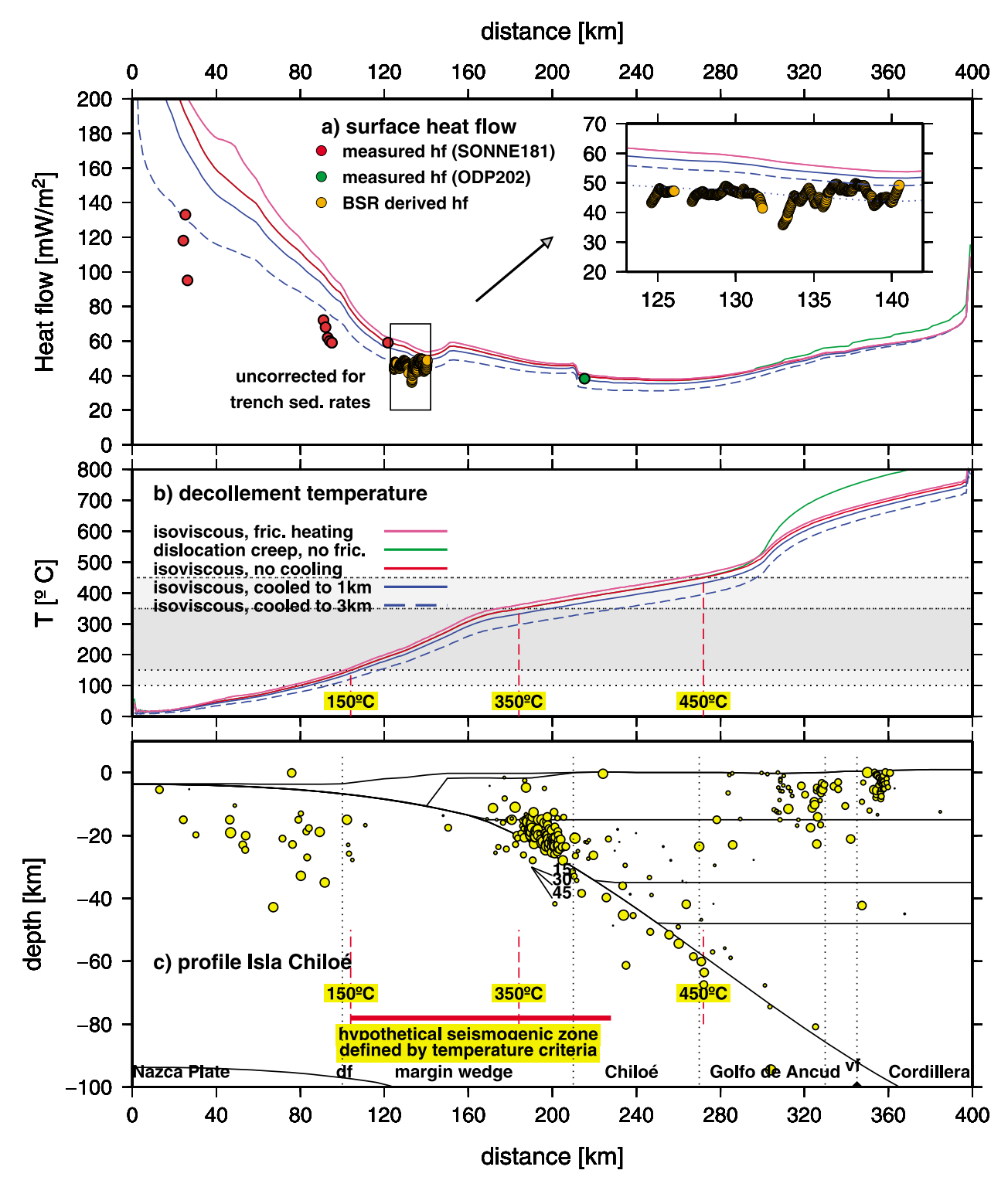

Figure 5. Model results for the southern profile (Isla Chiloé). (a) Observed heat flow given as red and green dots (red, Flueh and Grevemeyer [2005]; green, ODP 202) and BSR-derived heat flow as orange dots and modeled surface heat flow as lines. Blue, magenta, and red lines correspond to models with isoviscous rheology and different degrees of cooling and moderate frictional heating. Green lines correspond to models with a mantle wedge rheology of wet olivine. (b) Profiles of the modeled décollement temperature. The critical temperature ranges for the mechanical state of the plate contact $\left(150^{\circ} \mathrm{C}, 350^{\circ} \mathrm{C}\right.$, and $450^{\circ} \mathrm{C}$ ) are indicated by shaded boxes and vertical lines. (c) Geometry of our preferred model with hypocenters of Lange et al. [2007]. The critical temperature ranges of $150^{\circ} \mathrm{C}, 350^{\circ} \mathrm{C}$, and $450^{\circ} \mathrm{C}$ are indicated.

bending of the isotherms. The intersections of the subduction fault with the $350^{\circ} \mathrm{C}$ and $450^{\circ} \mathrm{C}$ isotherms lie beneath eastern Chiloé at depths of 30 and $55 \mathrm{~km}$, bracketing the mantle wedge tip. The thermally defined interseismic locked zone $\left(100^{\circ}-350^{\circ} \mathrm{C}\right)$ has a width of $105 \mathrm{~km}$ (but 116 and $138 \mathrm{~km}$ for the two hydrothermal cooling cases), while the thermally controlled seismogenic zone $\left(100^{\circ}\right.$ to midway between $350^{\circ}$ and $450^{\circ}$ ) is $149 \mathrm{~km}$ wide (Table 3). As discussed in section 3.2, the effect of a nonlinear mantle rheology does not affect the forearc and the $350^{\circ} \mathrm{C}$ to $450^{\circ} \mathrm{C}$ zone. Intense hydrothermal cooling of the incoming plate leads to a $>20 \mathrm{~km}$ landward shift and a widening of thermally controlled seismogenic zone.

[61] The modeled heat flow best fits the observed values if strong hydrothermal cooling (cooling depth $3 \mathrm{~km}$ ) is assumed (Figure 5a). This is particularly true west of the trench, where the GDH1 model produces heat flow values as high as $200 \mathrm{~mW} \mathrm{~m}^{-2}$, whereas measured values of Flueh and Grevemeyer [2005] scatter in the range of 90-140 $\mathrm{mW} \mathrm{m}^{-2}$ (see first cluster in Figure 5a). This effect of strong cooling of the Nazca Plate at the outer rise was already suspected by Contreras-Reyes et al. [2007]. The offset of 40-60 $\mathrm{mW} \mathrm{m}^{-2}$ 


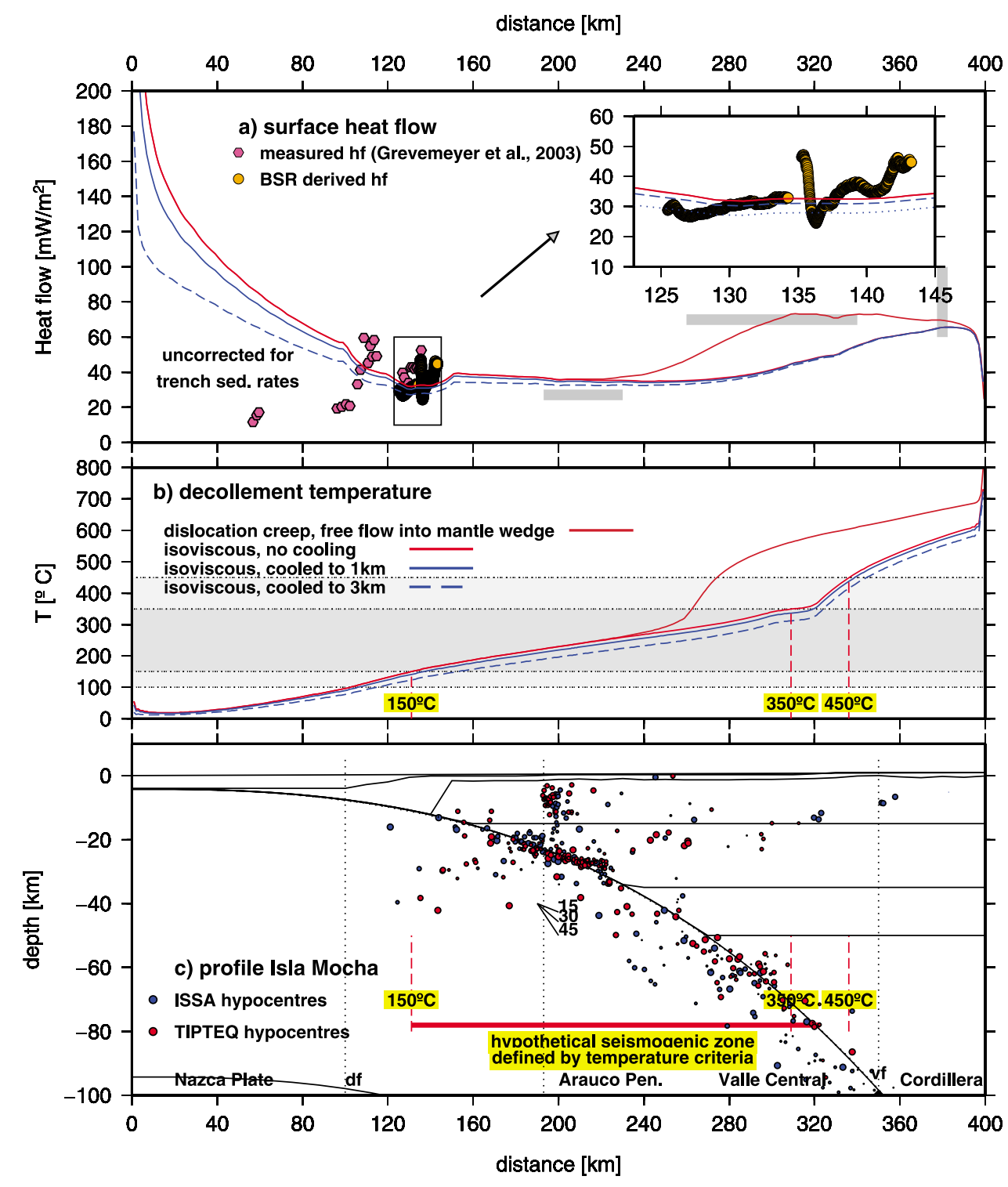

Figure 6. Model results for the Isla Mocha profile. (a) Measured surface heat flow values, BSR-derived heat flow, and modeled values. Solid blue line indicates models with a stagnant mantle wedge tip, brown line indicates models with mantle flow into the wedge tip, solid red line indicates normal ocean boundary temperature gradient, dashed blue line indicates oceanic crust effectively cooled to $1 \mathrm{~km}$ below seafloor, and dotted blue line oceanic crust effectively cooled to $3 \mathrm{~km}$ below seafloor. (b) Profiles of the modeled décollement temperature assuming degrees of cooling of the ocean crust. The critical temperature ranges for the mechanical state of the plate contact $\left(150^{\circ} \mathrm{C}, 350^{\circ} \mathrm{C}\right.$, and $\left.450^{\circ} \mathrm{C}\right)$ are indicated by shaded boxes and vertical lines. (c) Geometry of our preferred model with hypocenters of Bohm et al. [2002] and Haberland et al. [2006]. The critical temperature ranges for the mechanical state of the plate contact $\left(150^{\circ} \mathrm{C}, 350^{\circ} \mathrm{C}\right.$, and $\left.450^{\circ} \mathrm{C}\right)$ are indicated by vertical lines.

between measured and modeled heat flow values in the trench (see second cluster in Figure 7a) was expected, as heat flow anomalies near the toe of a young accretionary prism are often lower than predicted by the regional model [e.g., Hyndman et al., 1993; Grevemeyer et al., 2003]. Here, shortening and thickening of the accreting sediments spread the isotherms vertically, faster than thermal equilibrium can be re-established. The thickening represents downward mass advection with respect to the seafloor that reduces the vertical temperature gradient and hence heat flow. Values measured at ODP site 202 [Mix et al., 2003] fit well with any of our models with no-flow mantle wedge nose (see blue lines in Figure 5a) but are inconsistent with mantle wedge flow all the way to the mantle wedge tip (see red lines in Figure 5a).

\subsection{Profile Isla Mocha}

[62] Like the profile Isla Chiloé, our models of Isla Mocha show the effect of the draw-down of isotherms, but the effect is more pronounced as the $450^{\circ} \mathrm{C}$ isotherm reaches to 

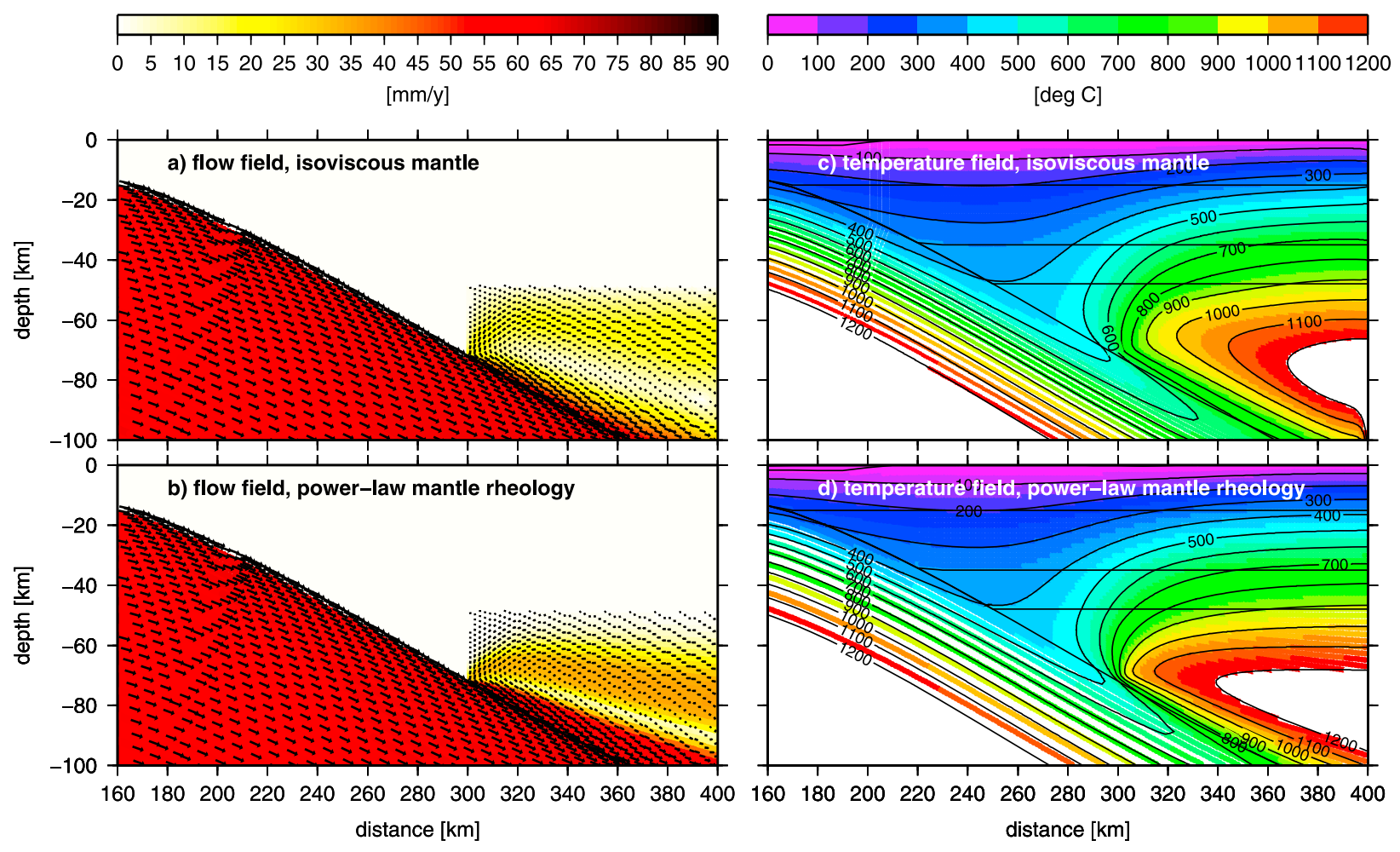

Figure 7. Comparison of ( $a$ and $b$ ) mantle flow fields and ( $c$ and $d)$ temperature fields for the isoviscous mantle case (Figures 7a and 7c) and the power law rheology (wet olivine rheology) case (Figures 7b and 7d) for the Isla Chiloé profile. The flow vector is given as arrows, and the flow velocity is in units of millimeters per year.

a depth exceeding $100 \mathrm{~km}$ (Figure 9). This isotherm meets the subduction fault at a depth of $70 \mathrm{~km}$ (Table 3 ). The zone of $350^{\circ} \mathrm{C}$ to $450^{\circ} \mathrm{C}$ lies beneath the Central Valley. The thermally predicted interseismic locked zone $\left(100^{\circ}-350^{\circ} \mathrm{C}\right)$ has a width of $209 \mathrm{~km}$, and the thermally defined seismogenic zone $\left(100^{\circ}\right.$ to midway between $350^{\circ}$ and $\left.450^{\circ}\right)$ is $222 \mathrm{~km}$ wide (Table 3). Over the range of tested values for rheology, and including hydrothermal cooling of the oceanic

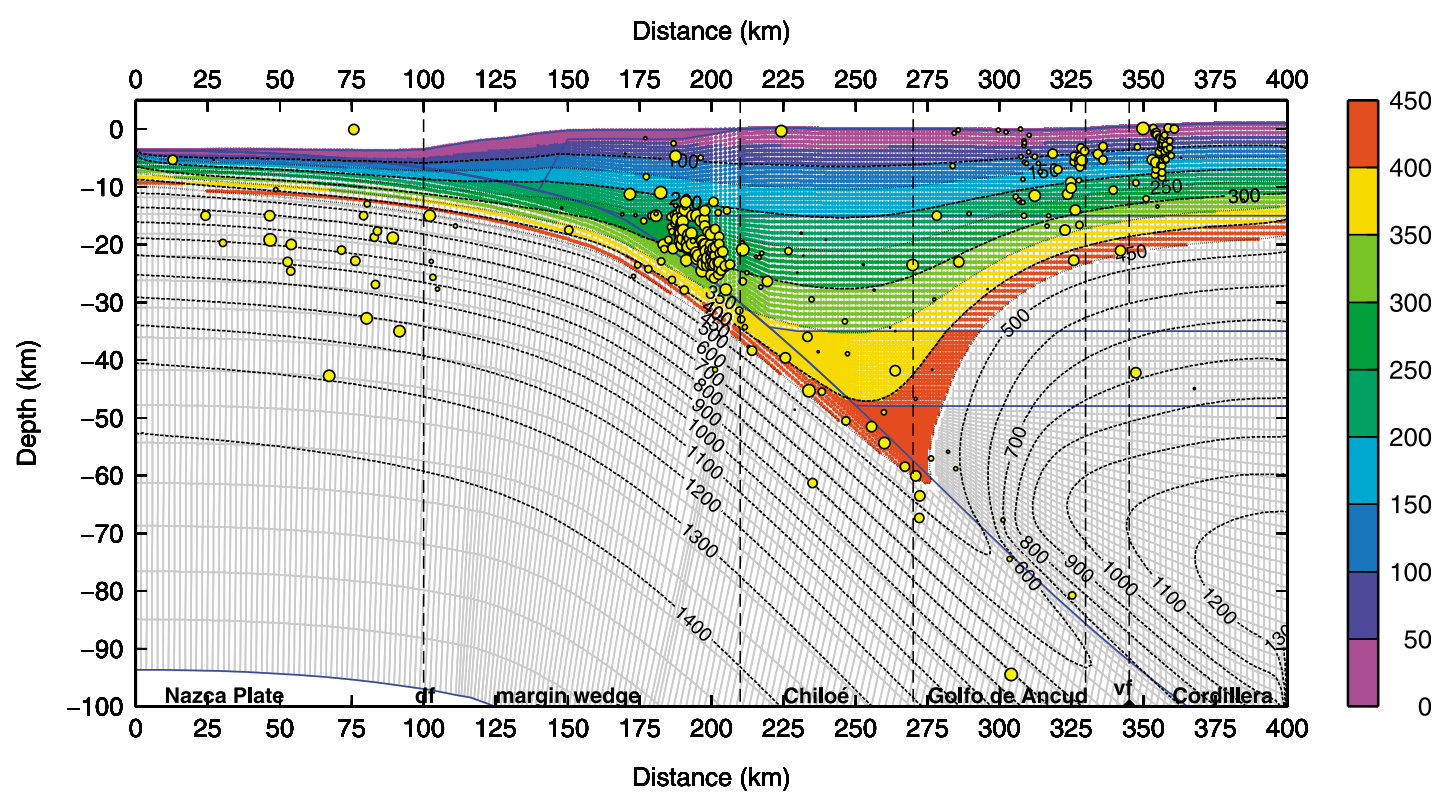

Figure 8. Temperature contours in degrees Celsius for our most robust model for the Isla Chiloé profile with isoviscous mantle wedge rheology. The geometry of the finite element mesh is underlain, and hypocenters are from Lange et al. [2007]. Abbreviations are as follows: df, deformation front; vf, volcanic front. 


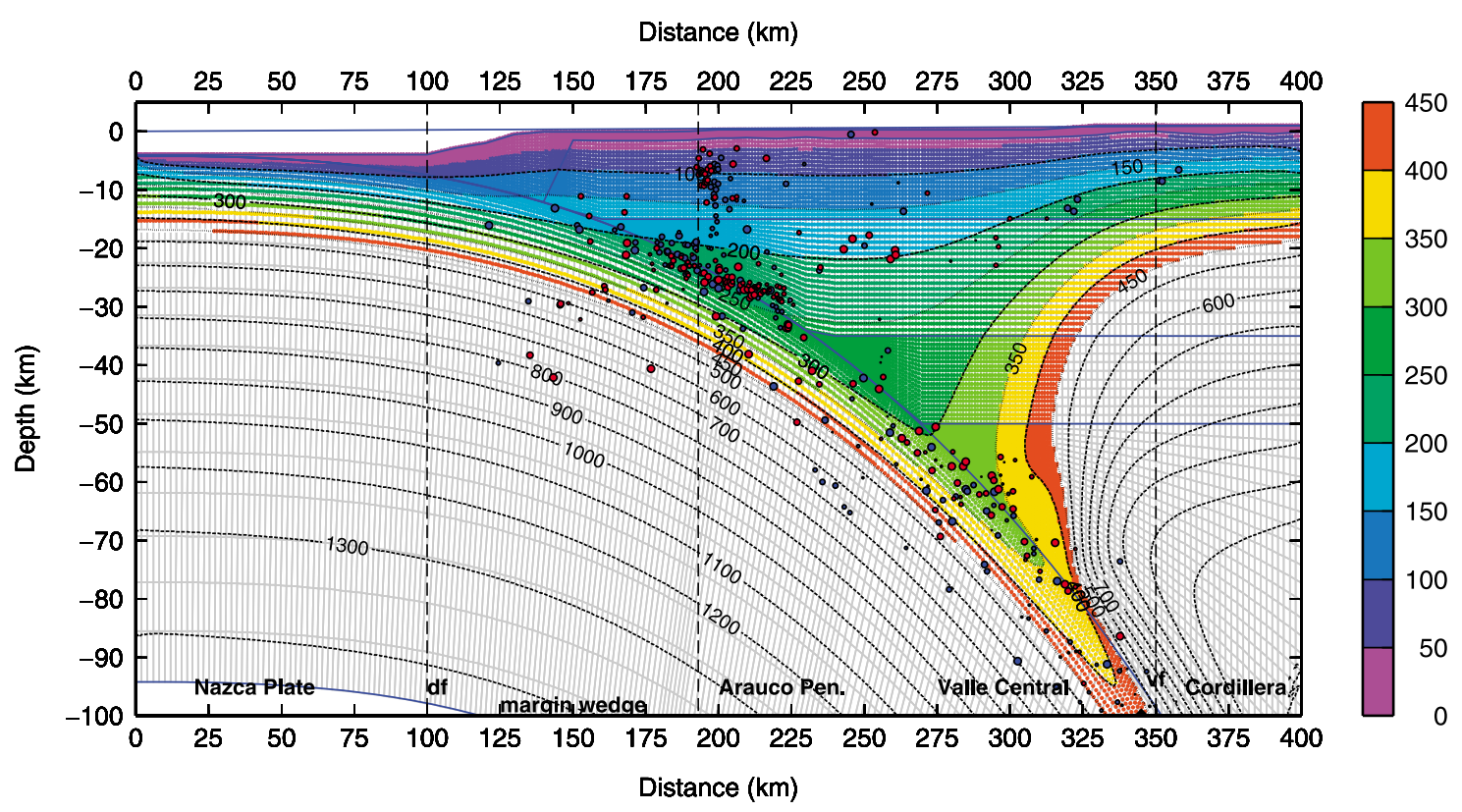

Figure 9. Temperature contours in degrees Celsius for our preferred model for the Isla Mocha profile with isoviscous mantle wedge rheology. The geometry of the finite element mesh is underlain, and hypocenters are from Bohm et al. [2002] and Haberland et al. [2006]. Abbreviations are as follows: df, deformation front; vf, volcanic front.

slab, the positions of the respective isotherms were robust within a few $\mathrm{km}$.

[63] The intersection of the $450^{\circ} \mathrm{C}$ isotherm with the plate interface lies deeper than the mantle wedge tip of $48 \mathrm{~km}$ for the Moho geometry used to explain gravity measurements [Alasonati-Tašárová, 2007]. According to Oleskevich et al. [1999], this would mean that the downdip end of the seismogenic zone is determined by the weak rheology of the hydrated mantle. If so, the seismogenic zone should terminate below the transition from the Coastal Cordillera to the Central Valley.

[64] Observed heat flow values of the continental slope agree reasonably well with all of our model curves, although they scatter significantly (Figure 6a). The very low values projected to our profile seaward of the trench at around $x=50 \mathrm{~km}$ may indicate hydrothermal cooling. Heat flow measurements on land are sparse, and their range is indicated as gray bars in Figure $6 \mathrm{a}$. The relatively high forearc values would fit better with a mantle wedge flow into the mantle wedge corner (see red curve in Figure 6a), but the evidence is weak.

\section{Discussion}

\subsection{Comparison Between the Model Profiles}

[65] A direct comparison shows that the subduction zone is much hotter in the south than in the north (Figures 8 and 9). A fault temperature of $150^{\circ} \mathrm{C}$ is reached at $x=104 \mathrm{~km}$, only $4 \mathrm{~km}$ landward of the deformation front in the southern profile, but it is not reached until below the coastline in the northern profile, with a landward shift of about $30 \mathrm{~km}$ (see Table 3 and Figure 7). This shift becomes larger for higher temperatures (e.g., $>100 \mathrm{~km}$ for the isotherm of $350^{\circ} \mathrm{C}$; see Table 3) with the result that zones defined by temperature intervals (e.g., $150-450^{\circ} \mathrm{C}$ ) widen from south to north by about $70 \mathrm{~km}$.
[66] If we take the assumption of Klotz et al. [2006] in which the width of the seismogenic zone equals the width of the locked zone $\left(100\right.$ to $\left.350^{\circ} \mathrm{C}\right)$ plus half of the width of the transition zone $\left(350^{\circ} \mathrm{C}\right.$ to $\left.450^{\circ} \mathrm{C}\right)$, then from south to north, the width of the thermally defined seismogenic zone increases from $126 \mathrm{~km}$ to $159 \mathrm{~km}$ (Table 3). If, alternatively, the contact of the hydrated mantle wedge with the subduction fault defines the downdip end of the seismogenic zone, the difference is slightly smaller $(126 \mathrm{~km}$ in the south, $152 \mathrm{~km}$ in the north). The thermally defined seismogenic zone would extend from close to the trench to below western Chiloé Island in the southern but from the coast to the transition of Arauco Peninsula to the Central Valley of Chile in the northern profile.

[67] It is notable that the geometry of the downgoing slab is similar in both profiles. There is a difference in the geometry of the continental Moho which leads to different depths of the mantle wedge tip (45 km for Isla Mocha and $31 \mathrm{~km}$ for Isla Chiloé), but it has little effect on the temperature field. The difference is mainly in the different thermal state of the incoming Nazca Plate.

\subsection{Comparison Between Temperature and Seismicity}

[68] The Isla Chiloé profile shows a pronounced clustering of the microseismicity in the $12-28 \mathrm{~km}$ depth range (see Figures $3 \mathrm{~b}$ and 8). Most of the seismicity occurs in the deeper part of the accretionary prism and terminates at the downgoing plate. For depths greater than $30 \mathrm{~km}$, the earthquakes probably occur within the slab. The downdip limit of the shallow cluster of seismicity corresponds to $\sim 325^{\circ} \mathrm{C}$ of the modeled temperature field. This temperature is in accordance with the seismic to aseismic (stable sliding) transition experimentally observed by Blanpied et al. [1991, 1995] for granitic material. For a clearer imaging of the seismicity deeper than $30 \mathrm{~km}$, longer recording periods than that of the data set of Lange et al. [2007] is necessary. 
[69] The Isla Mocha seismicity of Haberland et al. [2006] features a cluster along the plate boundary in the $18-30 \mathrm{~km}$ depth range, a seismicity minimum between 33 and $52 \mathrm{~km}$, and a lower zone of seismicity between 55 and $80 \mathrm{~km}$ (Figure 9). There is no distinct second layer of seismicity within the slab [e.g., Rietbrock and Waldhauser, 2004], but seismicity clearly extends deep into the mantle of the downgoing plate. The downdip limit of the shallow cluster corresponds to $\sim 250^{\circ} \mathrm{C}$ of the modeled temperature field. This temperature is lower than the postulated thermally controlled transition from velocity weakening to velocity strengthening [e.g., Tse and Rice, 1986; Blanpied et al., 1991, 1995; Hyndman and Wang, 1993].

[70] If we assume that the microseismicity characterizes interplate seismic coupling, we explain this behavior by sediment subduction. In the vicinity of the Isla Mocha the sediment input in the Chile Trench is highly variable, with a proposed subduction channel thickness of 0-2.0 km [Bangs and Cande, 1997; Sick et al., 2006]. It seems plausible that most of the earthquakes in the shallow cluster are due to failure in the subducted and accreted (meta)sediments as they are much weaker than the surrounding rocks of the mafic oceanic and the lower continental crust and should therefore control the bulk rheology.

[71] Röser [2007] and Heberer et al. [2010] reported that the sedimentary trench fill next to the Isla Mocha profile consists of approximately $45 \%$ plagioclase, $28 \%$ illite, $13 \%$ quartz, $7 \%$ chlorite, and $7 \%$ other phases. The same authors found that this composition does not change significantly within $100 \mathrm{~km}$ north and south of the profile. If muscovite at higher metamorphic conditions and/or quartz form an interconnected weak layering above a volume fraction of $\sim 20 \%$, they will control the bulk rheology of the rock [e.g., Carter et al., 1981; Handy, 1990, 1994; Tullis et al., 1991]. We propose that the deformation of these (meta)sediments controls the seismic to aseismic transition at the given lowtemperature conditions. The involved minerals may promote a change in deformation mode from localized and discontinuous brittle to distributed and continuous ductile deformation [Rutter, 1986; Kohlstedt et al., 1995]. This change can be realized by the initiation of one or more of the following deformation mechanisms:

[72] 1. Dislocation creep of quartz; it is predominant below the brittle to plastic transition at or above temperatures of $270-310^{\circ} \mathrm{C}$ in natural fault zones [e.g., Stöckhert et al., 1999; van Daalen et al., 1999; Stipp et al., 2002].

[73] 2. Reaction weakening by mica formation followed by continuous and distributed deformation [e.g., Mitra, 1978, 1984; Williams and Dixon, 1982; White and White, 1983; Evans, 1988; Wintsch et al., 1995; Imber et al., 2001; O'Hara, 2007]; this ductile deformation is realized by grain sizesensitive flow or by cleavage formation. For fine grained aggregates of muscovite this transition can occur at even lower temperature than the onset of dislocation creep of quartz.

[74] 3. Noncataclastic granular flow of mixed aggregates of fine grained quartz, plagioclase (albite) and muscovite; it is rheologically weaker than plastic deformation of pure aggregates at low metamorphic temperatures [e.g., Stünitz and Fitzgerald, 1993].

[75] 4. Semibrittle flow consisting of combined brittle (cataclastic) and plastic deformation mechanisms; it facilitates continuous, distributed deformation [e.g., Carter et al., 1981; Fredrich et al., 1989; Hirth and Tullis, 1994; White, 2001].

[76] Hence, a change in mode from localized and discontinuous brittle to distributed and continuous ductile deformation is feasible at $250^{\circ} \mathrm{C}$ or even cooler conditions for the predicted metasedimentary composition at the base of the accretionary prism and within the subduction channel. We explain the seismic to aseismic transition at $\sim 250^{\circ} \mathrm{C}$ in the Isla Mocha profile by such a change in deformation mode.

[77] The seismic to aseismic transition at $\sim 325^{\circ} \mathrm{C}$ in the Chiloé profile may also correspond to a similar change from brittle to ductile deformation but for a different rock composition; that is, quartz/feldspar dominated, with less illite (muscovite) and chlorite. Indeed, there is a change in sediment composition in the data of Röser [2007] to higher quartz contents toward the south. The seismic to aseismic (stable sliding) transition on preexisting fault planes [e.g., Blanpied et al., 1991, 1995] could be an additional cause for the disappearance of seismicity as discussed before. Alternatively, the hydrated mantle wedge may define the downdip end of the seismogenic zone in the Chiloé profile as suggested by Oleskevich et al. [1999]. However, there is a gap of a few $\mathrm{km}$ between them, and a small but distinct line of hypocenters continuously extends along the interface between the mantle wedge and the slab.

[78] We have to bear in mind however, that the microseismicity might not represent the downward limit of interplate seismic coupling, and that coupling may extend to greater depths than delineated by microseismicity recorded in a short time span. In fact, the 1960 earthquake may have nucleated at a greater depth [Engdahl and Villaseñor, 2002], and on 10 May 1975 a $M w=7.3$ interface earthquake occurred under the Arauco Peninsula as deep as 40-42 km [Tichelaar and Ruff, 1991].

\subsection{Comparison of Model Results With Deformation Measurements}

[79] The velocity field of the earth surface as measured by GPS stations gives indirect information on the state of coupling of the seismogenic zone, its position and width. On the basis of observed GPS velocity field of Chile and Argentina, Klotz et al. [2006] propose that the width of the geodetically estimated seismogenic zone remains rather constant between $22^{\circ} \mathrm{S}$ and $42^{\circ} \mathrm{S}$. The position of the downdip end of the seismogenic zone lies below the east coast of Chiloé Island, but below the transition of the Coastal Cordillera to the Central Valley at $38^{\circ} \mathrm{S}$.

[80] GPS measurements reported by Wang et al. [2007] show a northward increase in eastward plate velocities of the coastal area between our profiles. The authors' preferred explanation for this trend is a northward increase in depth of the downdip limit of the seismogenic zone and hence the width of the locked portion of the plate interface as a consequence of the increasing age of the subducting plate in the north. The thermally defined seismogenic zone of our models would fit well the model of Wang et al. [2007] regarding the width and general position of the locked zone and its landward termination and in particular regarding the northward increase in width.

[81] The above mentioned northward widening and deepening of the seismogenic zone seems to be at odds with 
reported distributions of coseismic slip of the 1960 earthquake. For example, Barrientos and Ward [1990] and Moreno et al. [2009], by inverting field observations of elevation changes, leveling data, and shear strains from triangulation surveys, reported slip distributions that terminate at a fairly constant depth (or distance from the deformation front) for the entire $\sim 900 \mathrm{~km}$ length of the rupture zone. However, one should be extremely cautious about these inversion results. The rupture was nearly entirely offshore, but almost all the observations were on land. In the southern half of the rupture zone, there were no leveling or triangulation data, and the inversion results were based on field observations of elevation changes that were obtained 8 years after the earthquake [Plafker and Savage, 1970]. Only two of these observations were far offshore (on islands), but they strongly control the inversion results. It these two observations were affected by local or rapid postseismic deformation, the entire southern half of the rupture model would be in large error. These data are far from adequate in resolving the slip distribution in the southern half of the rupture zone.

[82] If the seismogenic zone is delineated by microseismicity, its downdip end would terminate $30 \mathrm{~km}$ further west, indicating an almost constant width of $\sim 130 \mathrm{~km}$ with only a slight northward increase. This would be in agreement with the model of Klotz et al. [2006] but would fail to explain the GPS pattern reported by Wang et al. [2007]. Nevertheless, we have to bear in mind however, that the kinematic fault behavior may not necessarily be directly related to the occurrence of microseismicity, as a fully locked zone might be "silent" over interseismic periods.

\section{Summary and Conclusions}

[83] We developed thermal models for two trench-normal profiles across the subduction zone of southern central Chile. One profile is close to the northern end and nucleation point of the 1960 earthquake $\left(38.25^{\circ} \mathrm{S}\right.$, Isla Mocha profile), and the other is $500 \mathrm{~km}$ farther south $\left(42-43^{\circ} \mathrm{S}\right.$, Isla Chiloé profile). The effect of the age of the incoming plate on the temperature field is found to be the most important.

[84] The northern section is colder because the incoming slab has an age of $33 \mathrm{Ma} 100 \mathrm{~km}$ offshore and is characterized by a lower thermal gradient. The southern section is warmer owing to the younger and hotter incoming slab (13 Ma $100 \mathrm{~km}$ offshore). Therefore the intersection of the $450^{\circ} \mathrm{C}$ isotherm with the plate interface is deeper and further landward in the northern profile, with a depth of $88 \mathrm{~km}$ as compared to $61 \mathrm{~km}$ for the southern profile. The hypothetical seismogenic zone as defined by temperature is both wider and shifted landward for the northern profile.

[85] The downdip termination of microseismicity corresponds to $\sim 325^{\circ} \mathrm{C}$ in the Chiloé profile and to $\sim 250^{\circ} \mathrm{C}$ in the Isla Mocha profile. For Isla Mocha in the north, this low temperature does not correspond to the generally assumed unstable to stable sliding transition. However, large earthquakes like the $M w=9.51960$ earthquake and a $M w=7.3$ event in 1975 nucleated much deeper at 35-40 km depth and hence at higher temperatures. Nevertheless, even for a depth of $40 \mathrm{~km}$, the temperature is still lower than the $350^{\circ} \mathrm{C}$ threshold. As an alternative to a low-temperature threshold for the switch from stable to unstable sliding, we propose that the downdip end of the seismogenic zone is caused by a transition from discontinuous and localized brittle to continuous and distributed ductile deformation accommodated by semibrittle flow, dislocation creep and/or noncataclastic granular flow in the subducted and accretionary prism sediments. The Chiloé profile in the south can be explained by both a switch from unstable to stable sliding and a transition from discontinuous and localized brittle to continuous and distributed ductile deformation but for a slightly different composition of the subducted and accreted sediments. The second explanation would require deformation partitioning into the subduction channel similar to the Isla Mocha profile. Since there is considerable sediment subduction in the Chile Trench, and a deeply extending subduction channel has been proposed, the concentration of deformation in the rheologically weak (meta)sediments is plausible. In the Chiloé profile, the thermally constrained downdip end of the seismogenic zone as well as the termination of the upper seismicity cluster lie close to the tip of the hydrated mantle wedge that could alternatively serve to limit the width of the seismogenic zone.

[86] Our models support the notion of active cooling of the oceanic crust by hydrothermal circulation prior to subduction, particular in the southern region. Observed heat flows lie well below values predicted by a model that features a conductively cooled incoming plate. Frictional heating seems to be insignificant, as it would create an even larger mismatch between the measured and modeled surface heat flow even at moderate shear stress values of less than $54 \mathrm{MPa}$.

[87] The application of a power law rheology for dislocation creep of wet olivine for the rheology of the mantle leads to effective heat transport into the mantle wedge beneath the arc. The resultant temperature increase happens close to the arc and does not affect the positions of the 350 and $450^{\circ}$ temperatures along the subduction fault. The increase in the surface heat flow landward of the stagnant mantle wedge tip is insignificant. We lack land based heat flow data to test the effect for the Argentinean back arc.

[88] Regarding the extent of rupture of the 1960 earthquake, we can state, that for all of our models we have a slight increase in $w$ in the range of $30 \mathrm{~km}$ at maximum over the latitudinal distance of $530 \mathrm{~km}$ between the profiles. Apparently, no significant changes in the seismogenic zone properties had to be overcome, when the earthquake ruptured southward. The question of what ultimately delimits the 1960 earthquake segment remains.

[89] Acknowledgments. This work was funded by the Bundesministerium für Bildung und Forschung and the Deutschen Forschungsgemeinschaft in the frame of project TIPTEQ. This publication is contribution 209 of the Sonderforschungsbereich 574 Volatiles and Fluids in Subduction Zones at Kiel University. It is also Geological Survey of Canada contribution 20110069. We thank Ikuko Wada for assistance in the numerical modeling.

\section{References}

Alasonati-Tašárová, Z. (2007), Towards understanding the lithospheric structure of the southern Chilean subduction zone $\left(36^{\circ} \mathrm{S}-42^{\circ} \mathrm{S}\right)$ and its role in the gravity field, Geophys. J. Int., 170, 995-1014, doi:10.1111/ j.1365-246X.2007.03466.x.

Angermann, D., J. Klotz, and C. Reigber (1999), Space-geodetic estimation of the Nazca-South America Euler vector, Earth Planet. Sci. Lett., 171, 329-334, doi:10.1016/S0012-821X(99)00173-9.

Bangs, N. L., and S. C. Cande (1997), Episodic development of a convergent margin inferred from structures and processes along the southern Chilean margin, Tectonics, 16, 489-503, doi:10.1029/97TC00494. 
Barrientos, S. E., and S. N. Ward (1990), The 1960 Chile earthquake: Inversion for slip distribution from surface deformation, Geophys. J. Int., 103, 589-598, doi:10.1111/j.1365-246X.1990.tb05673.x.

Blanpied, M. L., D. A. Lockner, and J. D. Byerlee (1991), Fault stability inferred from granite sliding experiments at hydrothermal conditions, Geophys. Res. Lett., 18, 609-612, doi:10.1029/91GL00469.

Blanpied, M. L., D. A. Lockner, and J. D. Byerlee (1995), Frictional slip of granite at hydrothermal conditions, J. Geophys. Res., 100, 13,045-13,064, doi:10.1029/95JB00862.

Bohm, M., S. Luth, H. Echtler, G. Asch, K. Bataille, C. Bruhn, A. Rietbrock, and P. Wigger (2002), The southern Andes between $36^{\circ}$ and $40^{\circ} \mathrm{S}$ latitude: Seismicity and average seismic velocities, Tectonophysics, 356, 275-289, doi:10.1016/S0040-1951(02)00399-2.

Brace, W. F., and D. L. Kohlstedt (1980), Limits on lithospheric strength imposed by laboratory experiments, J. Geophys. Res., 85, 6248-6252, doi:10.1029/JB085iB11p06248.

Brigaud, F., and G. Vasseur (1989), Mineralogy, porosity and fluid control on thermal conductivity of sedimentary rocks, Geophys. J. Int. 98, 525-542, doi:10.1111/j.1365-246X.1989.tb02287.x.

Byrne, D. E., D. M. Davis, and L. R. Sykes (1988), Loci and maximum size of thrust earthquakes and the mechanics of the shallow region of subduction zones, Tectonics, 7, 833-857, doi:10.1029/TC007i004p00833.

Byrne, D. E., L. R. Sykes, and D. M. Davis (1992), Great thrust earthquakes and aseismic slip along the plate boundary of the Makran Subduction Zone, J. Geophys. Res., 97, 449-478, doi:10.1029/91JB02165.

Carter, N. L., D. A. Anderson, F. D. Hansen, and R. L. Kranz (1981), Creep and creep rupture of granitic rocks, in Mechanical Behavior of Crustal Rocks, Geophys. Monogr. Ser., vol. 24, edited by N. L. Carter et al., pp. 61-82, AGU, Washington, D. C.

Chopra, P. N., and M. S. Paterson (1984), The role of water in the deformation of dunite, J. Geophys. Res., 89, 7861-7876, doi:10.1029/ JB089iB09p07861.

Contreras-Reyes, E., I. Grevemeyer, E. R. Flueh, M. Scherwath, and M. Heesemann (2007), Alteration of the subducting oceanic lithosphere at the southern central Chile trench-outer rise, Geochem. Geophys. Geosyst. 8, Q07003, doi:10.1029/2007GC001632.

Contreras-Reyes, E., I. Grevemeyer, E. R. Flueh, and C. Reichert (2008), Upper lithospheric structure of the subduction zone offshore of southern Arauco peninsula, Chile, at $\sim 38^{\circ} \mathrm{S}$, J. Geophys. Res., 113, B07303, doi:10.1029/2007JB005569.

Currie, C. A., R. D. Hyndman, K. Wang, and V. Kostoglodov (2002), Thermal models of the Mexico subduction zone: Implications for the megathrust seismogenic zone, J. Geophys. Res., 107(B12), 2370, doi:10.1029/ 2001JB000886.

Currie, C. A., K. Wang, R. D. Hyndman, and J. He (2004), The thermal effects of steady-state slab-driven mantle flow above a subducting plate: The Cascadia subduction zone and backarc, Earth Planet. Sci. Lett., 223, 35-48, doi:10.1016/j.eps1.2004.04.020.

Davis, D. M., and R. von Huene (1987), Inferences on sediment strength and fault friction from structures at the Aleutian Trench, Geology, 15, 517-522, doi:10.1130/0091-7613(1987)15<517:IOSSAF>2.0.CO;2.

Davis, E. E., and T. J. Lewis (1984), Heat flow in a back-arc environment: Intermontane and Omineca crystalline belts, southern Canadian Cordillera, Can. J. Earth Sci., 21, 715-726, doi:10.1139/e84-077.

Delouis, B., J.-M. Nocquet, and M. Vallée (2010), Slip distribution of the February 27, 2010 Mw =8.8 Maule Earthquake, central Chile, from static and high-rate GPS, InSAR, and broadband teleseismic data, Geophys. Res. Lett., 37, L17305, doi:10.1029/2010GL043899.

DeMets, C., R. G. Gordon, D. F. Argus, and S. Stein (1990), Current plate motions, Geophys. J. Int., 101, 425-478, doi:10.1111/j.1365-246X.1990. tb06579.x.

Dickens, G. R., and M. S. Quinby-Hunt (1994), Methane hydrate stability in seawater, Geophys. Res. Lett., 21, 2115-2118, doi:10.1029/94GL01858.

Engdahl, E. R., and A. Villaseñor (2002), Global Seismicity: 1900-1999, in International Handbook of Earthquake and Engineering Seismology, Part A, edited by W. H. K. Lee et al., pp. 665-690, Elsevier, New York, doi:10.1016/S0074-6142(02)80244-3.

English, J. M., S. T. Johnston, and K. Wang (2003), Thermal modelling of the Laramide orogeny: Testing the flat-slab subduction hypothesis, Earth Planet. Sci. Lett., 214, 619-632, doi:10.1016/S0012-821X(03)00399-6.

Evans, J. P. (1988), Deformation mechanisms in granitic rocks at shallow crustal levels, J. Struct. Geol., 10, 437-443, doi:10.1016/0191-8141(88)90031-4.

Farías, M., G. Vargas, A. Tassara, S. Carretier, S. Baize, D. Melnick, and K. Bataille (2010), Land-level changes produced by the $M w 8.82010$ Chilean earthquake, Science, 329, 916, doi:10.1126/science.1192094.

Flueh, E., and I. Grevemeyer (2005), FS SONNE Cruise Report SO 181 TIPTEQ From the incoming plate to megathrust earthquakes, Rep. 06.12.2004. 26.02.2005, 533, pp., Leibniz-Inst. für Meereswissenschaften an der Univ. Kiel, Kiel, Germany.
Fredrich, J. T., B. Evans, and T. Wong (1989), Micromechanics of the brittle to plastic transition in Carrara marble, J. Geophys. Res., 94, 4129-4145, doi:10.1029/JB094iB04p04129.

Grevemeyer, I., and H. Villinger (2001), Gas hydrate stability and the assessment of heat flow through continental margins, Geophys. J. Int., 145, 647-660, doi:10.1046/j.0956-540x.2001.01404.x.

Grevemeyer, I., J. L. Diaz-Naveas, C. R. Ranero, H. W. Villinger, and Ocean Drilling Program Leg 202 Scientific Party (2003), Heat flow over the descending Nazca plate in central Chile, $32^{\circ} \mathrm{S}$ to $41^{\circ} \mathrm{S}$ : Observations from ODP Leg 202 and the occurrence of natural gas hydrates, Earth Planet. Sci. Lett., 213, 285-298, doi:10.1016/S0012-821X(03)00303-0. Grevemeyer, I., N. Kaul, J. L. Diaz-Naveas, H. W. Villinger, C. R. Ranero, and C. Reichert (2005), Heat flow and bending-related faulting at subduction trenches: Case studies offshore of Nicaragua and central Chile, Earth Planet. Sci. Lett., 236, 238-248, doi:10.1016/j.epsl.2005.04.048.

Haberland, C., A. Rietbrock, D. Lange, K. Bataille, and S. Hofmann (2006), Interaction between forearc and oceanic plate at the south-central Chilean margin as seen in local seismic data, Geophys. Res. Lett., 33, L23302, doi:10.1029/2006GL028189.

Hamza, V. M., and M. Munoz (1996), Heat flow map of South America, Geothermics, 25, 599-621, doi:10.1016/S0375-6505(96)00025-9.

Handy, M. R. (1990), The solid state flow of polymineralic rocks, J. Geophys. Res., 95, 8647-8661, doi:10.1029/JB095iB06p08647.

Handy, M. R. (1994), Flow laws for rocks containing two non-linear viscous phases: A phenomenological approach, J. Struct. Geol., 16, 287-301, doi:10.1016/0191-8141(94)90035-3.

Harris, R. N., and K. Wang (2002), Thermal models of the Middle America Trench at the Nicoya Peninsula, Costa Rica, Geophys. Res. Lett., 29(21), 2010, doi:10.1029/2002GL015406.

Harris, R. N., G. Spinelli, C. R. Ranero, I. Grevemeyer, H. Villinger, and U. Barckhausen (2010), Thermal regime of the Costa Rican convergen margin: 2. Thermal models of the shallow Middle America subduction zone offshore Costa Rica, Geochem. Geophys. Geosyst., 11, Q12S29, doi:10.1029/2010GC003273

Heberer, B., G. Roeser, J. H. Behrmann, M. Rahn, and A. J. Kopf (2010), Holocene sediments from the Southern Chile Trench: A record of active margin magmatism, tectonics and palaeoseismicity, J. Geol. Soc., 167, 539-553, doi:10.1144/0016-76492009-015.

Herron, E. M., S. C. Cande, and B. R. Hall (1981), An active spreading center collides with a subduction zone-A geophysical survey of the Chile Margin Triple Junction, Mem. Geol. Soc. Am., 154, 683-701.

Hino, R., T. Kanazawa, and A. Hasegawa (1996), Interplate seismic activity near the northern Japan Trench deduced from ocean bottom and landbased seismic observations, Phys. Earth Planet. Inter., 93, 37-52, doi:10.1016/0031-9201(95)03087-5.

Hirth, G., and D. Kohlstedt (2003), Rheology of the upper mantle and mantle wedge: A view from the experimentalists, in Inside the Subduction Factory, Geophys. Monogr. Ser., vol. 138, edited by J. M. Eiler, pp. 83-105, AGU, Washington, D. C.

Hirth, G., and J. Tullis (1994), The brittle-plastic transition in experimentally deformed quartz aggregates, J. Geophys. Res., 99, 11,731-11,747, doi:10.1029/93JB02873.

Hoffmann-Rothe, A., N. Kukowski, G. Dresen, H. Echtler, O. Oncken, J. Klotz, E. Scheuber, and A. Kellner (2006), Oblique convergence along the Chilean Margin: Partitioning, margin-parallel faulting and force interaction at the plate interface, in The Andes-Active Subduction Orogeny, edited by O. Oncken et al., pp. 125-146, Springer, Berlin.

Hyndman, R., and K. Wang (1993), Thermal constraints on the zone of major thrust earthquake failure: The Cascadia subduction zone, J. Geophys. Res., 98, 2039-2060, doi:10.1029/92JB02279.

Hyndman, R., K. Wang, T. Yuan, and G. D. Spence (1993), Tectonic sediment thickening, fluid expulsion and the thermal regime of subduction zone accretionary prisms: The Cascadia margin off Vancouver Island, J. Geophys. Res., 98, 21,865-21,876, doi:10.1029/93JB02391.

Hyndman, R., K. Wang, and M. Yamano (1995), Thermal constraints on the seismogenic portion of the southwestern Japan subduction thrust, J. Geophys. Res., 100, 15,373-15,392, doi:10.1029/95JB00153.

Imber, J., R. E. Holdsworth, C. A. Butler, and R. A. Strachan (2001), A reappraisal of the Sibson-Scholz fault zone model: The nature of the frictional to viscous ("brittle-ductile") transition along a long-lived, crustal-scale fault, Outer Hebrides, Scotland, Tectonics, 20, 601-624, doi:10.1029/2000TC001250.

Jaupart, C., and J. C. Mareschal (1999), The thermal structure and thickness of continental roots, Lithos, 48, 93-114, doi:10.1016/S0024-4937(99)00023-7. Jones, E. J. W. (1999), Marine Geophysics, 474 pp., John Wiley, New Jones,
York.

Karato, S.-I., M. S. Paterson, and J. D. Fitzgerald (1986), Rheology of synthetic olivine aggregates: Influence of grain size and water, J. Geophys. Res., 91, 8151-8176, doi:10.1029/JB091iB08p08151. 
Kaul, N., A. Rosenberger, and H. Villinger (2000), Comparison of measured and BSR-derived heat flow values, Makran accretionary prism, Pakistan, Mar. Geol., 164, 37-51, doi:10.1016/S0025-3227(99)00125-5.

Kendrick, E., M. Bevis, R. Smalley Jr., B. Brooks, R. B. Vargas, E. Lauria and L. P. S. Fortes (2003), The Nazca-South America Euler vector and its rate of change, J.S. Am. Earth Sci., 16, 125-131, doi:10.1016/S08959811(03)00028-2.

Klotz, J., A. Abolghasem, G. Khazaradze, B. Heinze, T. Vietor, R. Hackney, K. Bataille, R. Maturana, J. Viramonte, and R. Perdomo (2006), Longterm signals in the present-day deformation field of the central and southern Andes and constraints on the viscosity of the Earth's upper mantle, in The Andes-Active Subduction Orogeny, edited by O. Oncken et al., pp. 65-89, Springer, Berlin.

Kohlstedt, D. L., B. Evans, and S. J. Mackwell (1995), Strength of the lithosphere: Constraints imposed by laboratory experiments, J. Geophys. Res., 100, 17,587-17,602, doi:10.1029/95JB01460.

Krawcyzk, C. (2003), Amphibious seismic survey images plate interface at 1960 Chile Earthquake, Eos Trans. AGU, 84(32), 301, doi:10.1029/ 2003EO320001.

Krawcyzk, C., J. Mechie, S. Lüth, Z. Alasonati Tašárová, P. Wigger, M. Stiller, H. Brasse, H. P. Echtler, M. Araneda, and K. Bataille (2006), Geophysical signatures and active tectonics at the south-central Chilean margin, in The Andes-Active Subduction Orogeny, edited by O. Oncken et al., pp. 167-187, Springer, Berlin.

Lange, D., A. Rietbrock, C. Haberland, K. Bataille, T. Dahm, F. Tillmann, and E. R. Flüh (2007), Seismicity and geometry of the south Chilean subduction zone $\left(41.5^{\circ} \mathrm{S}-43.5^{\circ} \mathrm{S}\right)$ : Implications for controlling parameters, Geophys. Res. Lett., 34, L06311, doi:10.1029/2006GL029190.

Langseth, M. G., and E. A. Silver (1996), The Nicoya Convergent MarginA region of exceptionally low heat flow, Geophys. Res. Lett., 23, 891-894, doi:10.1029/96GL00733.

Marone, C., and C. H. Scholz (1988), The depth of seismic faulting and the upper transition from stable to unstable slip regimes, Geophys. Res. Lett. 15, 621-624, doi:10.1029/GL015i006p00621.

Mei, S., and D. L. Kohlstedt (2000), Influence of water on plastic deformation of olivine aggregates: 2. Dislocation creep regime, J. Geophys. Res., 105, 21,471-21,481, doi:10.1029/2000JB900180.

Mitra, G. (1978), Ductile deformation zones and mylonites: The mechanical processes involved in the deformation of crystalline basement rocks, Am. J. Sci., 278, 1057-1084, doi:10.2475/ajs.278.8.1057.

Mitra, G. (1984), Brittle to ductile transition due to large strains along the White Rock thrust, Wind River mountains, Wyoming, J. Struct. Geol., 6(1-2), 51-61.

Mix, A. C., et al. (2003) Proceedings of the Ocean Drilling Program: Initial Report, vol. 202, Ocean Drill. Program, College Station, Tex., doi:10.2973/odp.proc.ir.202.2003.

Molnar, P., and P. England (1990), Temperatures, heat flux and frictional stress near major thrust faults, J. Geophys. Res., 95, 4833-4856, doi:10.1029/JB095iB04p04833.

Moore, J. C., and D. M. Saffer (2001), Updip limit of the seismogenic zone beneath the accretionary prism of southwest Japan: An effect of diagenetic to low-grade metamorphic processes and increasing effective stress, Geology, 29, 183-186, doi:10.1130/0091-7613(2001)029<0183: ULOTSZ $>2.0 . \mathrm{CO} ; 2$

Moreno, M. S., J. Bolte, J. Klotz, and D. Melnick (2009), Impact of megathrust geometry on inversion of coseismic slip from geodetic data: Application to the 1960 Chile earthquake, Geophys. Res. Lett., 36, L16310, doi:10.1029/2009GL039276.

Munoz, A. E. D., and V. M. Hamza (1993), Heat flow and temperature gradients in Chile, Stud. Geophys. Geod., 37, 315-348, doi:10.1007/ BF01624604

O'Hara, K. (2007), Reaction weakening and emplacement of crystalline thrusts: Diffusion control on reaction rate and strain rate, J. Struct. Geol., 29, 1301-1314.

Oleskevich, D. A., R. D. Hyndman, and K. Wang (1999), The updip and downdip limits to great subduction earthquakes: Thermal and structura models of Cascadia, south Alaska, SW Japan, and Chile, J. Geophys. Res., 104, 14,965-14,991, doi:10.1029/1999JB900060.

Oncken, O., G. Chong, G. Franz, P. Giese, H.-J. Götze, V. A. Ramos, M. R. Strecker, and P. Wigger (Eds.) (2006), The Andes-Active Subduction Orogeny, Springer, Berlin.

Pacheco, J. F., and L. R. Sykes (1992), Seismic moment catalog of large shallow earthquakes, 1900 to 1989, Bull. Seismol. Soc. Am., 82, 1306-1349.

Pacheco, J. F., L. R. Sykes, and C. H. Scholz (1993), Nature of seismic coupling along simple plate boundaries of the subduction type, J. Geophys. Res., 98, 14,133-14,159, doi:10.1029/93JB00349.

Peacock, S. M., and R. D. Hyndman (1999), Hydrous minerals in the mantle wedge and the maximum depth of subduction thrust earthquakes, Geophys. Res. Lett., 26, 2517-2520, doi:10.1029/1999GL900558.
Peacock, S. M., and K. Wang (1999), Seismic consequences of warm versus cool subduction metamorphism: Examples from southwest and northeast Japan, Science, 286, 937-939, doi:10.1126/science.286.5441.937. Plafker, G., and J. C. Savage (1970), Mechanism of the Chilean earthquakes of May 21 and 22, 1960, Geol. Soc. Am. Bull., 81, 1001-1030, doi:10.1130/0016-7606(1970)81[1001:MOTCEO]2.0.CO;2.

Pollack, H. N., S. J. Hurter, and J. R. Johnson (1993), Heat flow from the Earth's interior: Analysis of the global data set, Rev. Geophys., 31, 267-280, doi:10.1029/93RG01249.

Ranalli, G., and D. Murphy (1987), Rheologic stratification of the lithosphere, Tectonophysics, 132, 281-295, doi:10.1016/0040-1951(87)90348-9.

Ranero, C. R., R. V. Huene, R. W. Weinrebe, and C. Reichert (2006), Tectonic processes along the Chile Convergent Margin, in The AndesActive Subduction Orogeny, edited by O. Oncken et al., pp. 91-123, Springer, Berlin.

Rietbrock, A., and F. Waldhauser (2004), A narrowly spaced doubleseismic zone in the subducting Nazca Plate, Geophys. Res. Lett., 31 , L10608, doi:10.1029/2004GL019610.

Röser, G. (2007), Petrography, physical properties, and geotechnical behavior of modern sediments, Southern Chile Trench, Ph.D. thesis, Albert-Ludwigs-Univ., Freiburg, Germany.

Rudnick, R. L., W. F. McDonough, and R. J. O’Connell (1998), Thermal structure, thickness and composition of continental lithosphere, Chem. Geol., 145, 395-411, doi:10.1016/S0009-2541(97)00151-4.

Ruff, L. J., and B. W. Tichelaar (1996), What controls the seismogenic plate interface in subduction zones?, in Subduction Top to Bottom, Geophys Monogr. Ser., vol. 96, edited by G. E. Bebout et al., pp. 105-111, AGU, Washington, D. C.

Rummel, F. (1982), Fracture and flow of rocks and minerals, in Physical Properties of Rocks, edited by G. Angenheister, pp. 141-240, Springer, Berlin.

Rutter, E. H. (1986), On the nomenclature of mode of failure transitions in rocks, Tectonophysics, 122, 381-387, doi:10.1016/0040-1951(86)90153-8. Saffer, D. M., and C. Marone (2003), Comparison of smectite- and illiterich gouge frictional properties: Application to the updip limit of the seismogenic zone along subduction megathrusts, Earth Planet. Sci. Lett., 215, 219-235, doi:10.1016/S0012-821X(03)00424-2.

Scherwath, M., E. Flueh, I. Grevemeyer, F. Tilmann, E. Contreras-Reyes, and W. Weinrebe (2006), Investigating subduction zone processes in Chile, Eos Trans. AGU, 87(27), 265-272, doi:10.1029/2006EO270001.

Scherwath, M., E. Contreras-Reyes, E. R. Flueh, I. Grevemeyer, A. Krabbenhoeft, C. Papenberg, C. J. Petersen, and R. W. Weinrebe (2009), Deep lithospheric structures along the southern central Chile Margin from wide-angle $P$ wave modelling, Geophys. J. Int., 179, 579-600, doi:10.1111/j.1365-246X.2009.04298.x.

Scholz, C. S. (1990), The Mechanics of Earthquakes and Faulting, 439 pp., Cambridge Univ. Press, Cambridge, U. K.

Sick, C., et al. (2006), Seismic images of accretive and erosive subduction zones from the Chilean Margin, in The Andes-Active Subduction Orogeny, edited by O. Oncken et al., pp. 147-171, Springer, Berlin.

Stein, C., and S. Stein (1992), A model for the global variation in oceanic depth and heat flow with lithospheric age, Nature, 359, 123-129.

Stern, R. J. (2002), Subduction zones, Rev. Geophys., 40(4), 1012, doi:10.1029/2001RG000108.

Stipp, M., H. Stünitz, R. Heilbronner, and S. M. Schmid (2002), The eastern Tonale fault zone: A "natural laboratory" for crystal plastic deformation of quartz over a temperature range from $250^{\circ} \mathrm{C}$ to $700^{\circ} \mathrm{C}$, J. Struct. Geol., 24, 1861-1884, doi:10.1016/S0191-8141(02)00035-4.

Stöckhert, B., M. R. Brix, R. Kleinschrodt, A. J. Hurford, and R. Wirth (1999), Thermochronometry and microstructures of quartz-A comparison with experimental flow laws and predictions on the temperature of the brittle-plastic transition, J. Struct. Geol., 21, 351-369, doi:10.1016/ S0191-8141(98)00114-X.

Stünitz, H., and J. D. Fitzgerald (1993), Deformation of granitoids at low metamorphic grade: 2. Granular flow in albite-rich mylonites, Tectonophysics, 221, 299-324, doi:10.1016/0040-1951(93)90164-F.

Tassara, A., H. J. Götze, S. Schmidt, and R. Hackney (2006), Threedimensional density model of the Nazca plate and the Andean continental margin, J. Geophys. Res., 111, B09404, doi:10.1029/2005JB003976.

Tebbens, S. F., S. C. Cande, L. Kovacs, J. C. Parra, J. L. LaBrecque, and H. Vergara (1997), The Chile Ridge: A tectonic framework, J. Geophys. Res., 102, 12,035-12,059, doi:10.1029/96JB02581.

Tichelaar, B. W., and L. J. Ruff (1991), Seismic coupling along the Chilean Subduction Zone, J. Geophys. Res., 96, 11,997-12,022, doi:10.1029/ 91JB00200.

Tichelaar, B. W., and L. J. Ruff (1993), Depth of seismic coupling along subduction zones, J. Geophys. Res., 98, 2017-2037, doi:10.1029/ 92JB02045. 
Tse, S. T., and J. R. Rice (1986), Crustal earthquake instability in relation to the depth variation of frictional slip properties, J. Geophys. Res., 98, 2017-2037.

Tullis, T. E., F. G. Horowitz, and J. Tullis (1991), Flow laws for polyphase aggregates from end member flow laws, J. Geophys. Res., 96, 8081-8096, doi:10.1029/90JB02491.

van Daalen, M., R. Heilbronner, and K. Kunze (1999), Orientation analysis of localized shear deformation in quartz fibres at the brittle-ductile transition, Tectonophysics, 303, 83-107, doi:10.1016/S0040-1951(98)00264-9.

van Keken, P. E., et al. (2008), A community benchmark for subduction zone modeling, Phys. Earth Planet. Inter., 171, 187-197, doi:10.1016/ j.pepi.2008.04.015.

Völker, D., M. Wiedicke, S. Ladage, C. Gaedicke, C. Reichert, K. Rauch, W. Kramer, and C. Heubeck (2006), Latitudinal variation in sedimentary processes in the Peru-Chile Trench off central Chile, in The AndesActive Subduction Orogeny, edited by O. Oncken et al., pp. 193-216, Springer, Berlin.

Vrolijk, P. (1990), On the mechanical role of smectite in subduction zones, Geology, 18, 703-707, doi:10.1130/0091-7613(1990)018<0703: OTMROS $>2.3$.CO;2.

Wada, I., and K. Wang (2009), Common depth of slab-mantle decoupling: Reconciling diversity and uniformity of subduction zones, Geochem. Geophys. Geosyst., 10, Q10009, doi:10.1029/2009GC002570.

Wada, I., K. Wang, J. He, and R. D. Hyndman (2008), Weakening of the subduction interface and its effects on surface heat flow, slab dehydration, and mantle wedge serpentinization, J. Geophys. Res., 113, B04402, doi:10.1029/2007JB005190.

Wallace, L. M., et al. (2009), Characterizing the seismogenic zone of a major plate boundary subduction thrust: Hikurangi Margin, New Zealand, Geochem. Geophys. Geosyst., 10, Q10006, doi:10.1029/2009GC002610.

Wang, K. (2010), Finding fault in fault zones, Science, 329, 152-153, doi:10.1126/science. 1192223
Wang, K., and J. H. He (2008), Effects of frictional behavior and geometry of subduction fault on coseismic seafloor deformation, Bull. Seismol. Soc. Am., 98, 571-579, doi:10.1785/0120070097.

Wang, K., and Y. Hu (2006), Accretionary prisms in subduction earthquake cycles: The theory of dynamic Coulomb wedge, J. Geophys. Res., 111, B06410, doi:10.1029/2005JB004094.

Wang, K., Y. Hu, M. Bevis, E. Kendrick, R. Smalley Jr., R. B. Vargas, and E. Lauría (2007), Crustal motion in the zone of the 1960 Chile earthquake: Detangling earthquake-cycle deformation and forearc-sliver translation, Geochem. Geophys. Geosyst., 8, Q10010, doi:10.1029/ 2007 GC001721.

Wessel, P., and W. H. F. Smith (1998), New, improved version of generic mapping tools released, Eos Trans. $A G U, 79(47), 579$.

White, J. C., and S. H. White (1983), Semi-brittle deformation within the Alpine fault zone, New Zealand, J. Struct. Geol., 5, 579-589, doi:10.1016/0191-8141(83)90070-6.

White, S. (2001), Textural and microstructural evidence for semi-brittle flow in natural fault rocks with varied mica contents, Int. J. Earth Sci., 90, 14-27, doi:10.1007/s005310000166

Williams, G., and J. Dixon (1982), Reaction and geometrical softening in granitoid mylonites, Textures Microstruct., 4, 223-239, doi:10.1155/ TSM.4.223.

Wintsch, R. P., R. Christoffersen, and A. K. Kronenberg (1995), Fluid-rock reaction weakening of fault zones, J. Geophys. Res., 100, 13,021-13,032, doi:10.1029/94JB02622.

I. Grevemeyer, M. Stipp, and D. Völker, Collaborative Research Center SFB 574, IFM-GEOMAR Leibniz Institute for Marine Sciences, University of Kiel, Wischhofstr. 1-3, D-24148 Kiel, Germany. (igrevemeyer@ifmgeomar.de; mstipp@ifm-geomar.de; dvoelker@ifm-geomar.de)

J. He and K. Wang, Pacific Geoscience Centre, Geological Survey of Canada, PO Box 6000, 9860 West Saanich Rd., Sidney, BC V8L 4B2, Canada. (jhe@nrcan.gc.ca; kwang@nrcan.gc.ca) 